\title{
The Social Foundations of Defamation Law: Reputation and the Constitution
}

\author{
Robert C. Post $\uparrow$
}

The common law of defamation has long been viewed as an intellectual wasteland, "perplexed with minute and barren distinctions." Dean Prosser, for example, began his discussion of the law of defamation with the proposition, which he took to be incontestable, that "there is a great deal of the law of defamation which makes no sense," in that it contains "anomalies and absurdities for which no legal writer ever has had a kind word."2 It was with considerable relief, therefore, that in 1964 legal commentators turned their attention to the difficult and fascinating constitutional questions raised by New York Times Co. v. Sullivan, ${ }^{3}$ which for the first time subjected the law of defamation to the regulation of the first amendment. Discussion of the law of defamation has been dominated ever since by the constitutional perspective. ${ }^{4}$

Froin this elevated perspective the purpose of defamation law looks, paradoxically, simple enough. The common law of slander and libel is designed to effectuate society's "pervasive and strong interest in preventing and redressing attacks upon reputation."s The trick is then to "balance the State's interest in compensating private individuals for injury to their reputation against the First Amendment interest in protecting this

$\dagger$ Acting Professor of Law, Boalt Hall School of Law, University of California, Berkeley.

This article would not have been possible without the advice and encouragement of Jerome Skolnick. Many of the ideas it contains emerged from a seminar that we taught together on the sociology of libel, and during the dark hours of composition Jerry was a constant source of assistance, insight, and wise counsel. No one could have been a kinder, more selfless, or more supportive colleague. I am also grateful for the comments and assistance of Paul Mishkin, Jan Vetter, Franklin Zimring, Melvin Eisenberg, Sheldon Messinger, Sanford Levinson, David Lieberman, and Jeremy Waldron. Thanks are also due to Mark Ryland, Marty Slaughter, and Jerry Friedberg for their help and research, and to the Center for the Study of Law and Society for its financial support.

1. F. Pollock, The Law of ToRTs 243 (13th ed. 1929).

2. W. Prosser, HANDBOOK OF THE LAW OF TORTS 737 (4th ed. 1971).

3. 376 U.S. 254 (1964).

4. See, e.g., R. Sack, Libel, Slander and Related Problems 1 (1980). This tendency perhaps rcached its zenith in a recent article which began: "American libel law came into being only 22 years ago, with the Supreme Court's 1964 decision in the New York Times Co. v. Sullivan case." Sanford, Some Lessons in Libel: A Primer on the Danger Zones, WASH. J. Rev., March 1986, at 28.

5. Rosenblatt v. Baer, 383 U.S. 75, 86 (1966). 
type of expression."

The image of balancing, however, implies that the characteristics of each of the competing interests have been assessed and evaluated. Although there has been considerable scholarly attention directed to the definition and articulation of "the First Amendment interest" in protectmg expression, there has been relatively little discussion of the nature and importance of "the State's interest" in protecting reputation. The latter inquiry, of course, requires an exploration into the obscure purposes and functions of common law defamation, which is not a journey that many modern commentators have been willing to undertake, especially given the attractive and well-travelled alternative routes of constitutional analysis. It is all too easy to assume that everyone knows the value of reputation, and to let the matter drop with the obligatory reference to Shakespeare's characterization of a "good name" as the "immediate jewel" of the soul. ${ }^{7}$

Reputation, however, is a mysterious thing. The common law, as a rule, has "not attempted to define reputation."8 The dictionary describes it as the "common or general estimate of a person with respect to character or other quatities." Reputation thus inheres in the social apprehension that we have of each other. In one sense, of course, virtually all of our social relationships consist of such apprehension, and it is not clear what it would mean for them all to be "protected" by defamation law. But by looking carefully at the nature of the "injuries affecting a man's reputation or good name"10 defamation law is actually designed to redress, one can uncover a more focused image of the exact kinds of

6. Dunn \& Bradstreet, Inc. v. Greenmoss Builders, Inc., 105 S.Ct. 2939, 2944-45 (1985) (opinion of Powell, J.).

7. W. ShaKeSPEARE, OTHELlo, act III, scene iii, 11 155-61:

Good name in man and woman, dear my lord,

Is the immediate jewel of their souls:

Who steals my purse steals trash; 'tis something, nothing,

'Twas mine 'tis his, and has been slave to thousands;

But he that filches from me my good name

Robs me of that which not enriches him,

And makes me poor indeed.

See, e.g., Pierce v. Capital Cities Communications, Inc., 576 F.2d 495, 505 n.33 (3d Cir. 1978); Maheu v. Hughes Tool Co., 569 F.2d 459, 480 n.14 (9th Cir. 1977); Embrey v. Holly, 293 Md. 128, 130 n.2, 442 A.2d 966, 967 n.2 (1982); Jadwin v. Minneapolis Star and Tribune Co., 367 N.W.2d 476, 491 n.20 (Minn. 1985); Onassis v. Christian Dior - New York, Inc., 122 Misc.2d 603, 610, 472 N.Y.S.2d 254, 260 (1984); Adamson v. Bonesteele, 295 Or. 815, 821 n.4, 671 P.2d 693, 696 n.4 (1983); Kernick v. Dardanell Press, 428 Pa. 288, 292, 236 A.2d 191, 193 (1967); Crump v. Beckley Newspapers, Inc., 320 S.E.2d 70, 76 n.2 (W. Va. 1984); Denny v. Mertz, 106 Wis.2d 636, 658 n.33, 318 N.W.2d 141, 152 n.33 (1982); P.F. CARTER-RUCK, L1BEL \& SLANDER 19 (1972); Note, The Interest in Limiting the Disclosure of Personal Information: A Constitutional Analysis, 36 VAND. L. Rev. 139, 160-61 (1983); $c f$. Z. Chafee, Government and Mass Communications 96 (1965).

8. Developments in the Law-Defamation, 69 HARV. L. REV. 875, 877 (1956).

9. 8 OXFORD ENGLish DICTIONARY 496 (James Murray cd. 1910).

10. 3 W. Blackstone, Commentaries on the Laws of ENGLAND * 123 . 
social apprehension that defamation law considers "normal," or "desirable," or deserving of the law's protection. In this sense defamation law presupposes an image of how people are tied together, or should be tied together, in a social setting. As this image varies, so will the nature of the reputation that the law of defamation seeks to protect.

This suggests that an evaluation of the state's interest in reputation can have no single outcome, for the meaning and significance of reputation will depend upon the kinds of social relationships that defamation law is designed to uphold. In this Article I will sketch three distinct concepts of reputation that the common law of defamation has at various times in its history attempted to protect: reputation as property, as honor, and as dignity. These three concepts are not the only possible concepts of reputation, but they have had by far the most important impact on the development of the common law of defamation. Each corresponds to an implicit and discrete image of the good and well-ordered society. Each is an ideal or pure type in the Weberian sense; ${ }^{11}$ that is, they are as types analytically distinct, although in actuality there may be, and indeed must be, some overlap. ${ }^{12}$ Each has exercised a significant influence on common law doctrine, pushing that doctrine in diverse and divergent directions. And each weighs very differently in the balance against our constitutional interest in freedom of expression.

I

THREE CONCEPTS OF REPUTATION

\section{A. Reputation as Property}

The concept of reputation that is most easily available to contemporary observers is that of reputation in the marketplace. This concept of reputation can be understood as a form of intangible property akin to goodwill. ${ }^{13}$ It is this concept of reputation that underlies our image of the merchant who works hard to become known as creditworthy or of the carpenter who strives to achieve a name for quality workmanship. Such a reputation is capable of being earned, in the sense that it can be acquired as a result of an individual's efforts and labor. Thomas Starkie

11. 1 M. WeBer, ECONOMY AND SOCIETY 217 (G. Roth \& C. Wittich eds. 1968).

12. The historical relationship among these three concepts raises complex questions that will require further investigation. This Article will attempt simply to identify and analyze the concepts, and to demonstrate their influence on common law defamation.

13. For a discussion of the concept of "goodwill" as a property right "enforceable in law and in equity," see I A. Dewing, The Financial Policy of CoRporations 285 n.j (1953). For a discussion of the history of the concept of "goodwill," see G.R. CATLETT \& N.O. OLSON, AcCOUNTING FOR GOODWILL 9-21 (1968). An economic analysis of the concept of "reputation" may be found in Holmstrom, The Provision of Services in a Market Economy, in MANAGiNG THE SERVICE ECONOMY 197-207 (R. Inman ed. 1985). 
well described this concept of reputation over a hundred and fifty years ago:

Reputation itself, considered as the object of injury, owes its being and importance chiefly to the various artificial relations which are created as society advances.

The numerous gradations of rank and authority, the honours and distinctions extended to the exertion of talent in the learned professions, the emoluments acquired by mechanical skill and ingenuity, under the numerous subdivisions of labour, the increase of commerce, and particularly the substitution of symbols for property in commercial intercourse-all, in different degrees, connect themselves with credit and character, affixing to them a value, not merely ideal, but capable of pecuniary admeasurement, and consequently recoinmending thein as the proper objects of legal protection. ${ }^{14}$

For Starkie the reputation protected by defamation law is something that a person can earn through "the exertion of talent" or the exercise of "mechanical skill and ingenuity." To injure such a reputation without justification is to unjustly destroy the results of an individual's labor. The resulting loss is "capable of pecuniary admeasurement" because the value of reputation is determined by the inarketplace in exactly the same inanner that the inarketplace determines the cash value of any property loss. ${ }^{15}$

The concept of reputation as property explains why defamation law proscribes aspersions on an individual's character even in contexts that are not narrowly oriented toward business relationships. This is because character can be viewed-and at the time Starkie was writing was in fact viewed-as "the fruit of personal exertion." 16 On this account character "is not inherited from parents; it is not created by external advantages; it is no necessary appendage of birth, or wealth, or talents, or station; but the result of one's own endeavors, - the fruit and reward of good principles, inanifested in a course of virtuous and honorable action."17 Such character is understood to be a form of "capital" since it "creates funds" and the potential for "patronage and support."18 The reputation for good character, as distinct from the possession of the character itself, can

14. T. Starkie, a Treatise on the Law of Slander, Libel, Scandalum Magnatum AND FALSE RUMOURS XX (New York 1826).

15. Thomas Hobbes had by the seventeenth century already equated reputation with monetary value. To Hobbes the "Value, or WORTH of a man, is, as of all other things, his Price ...," and the "manifestation of the Value we set on one another, is that which is commonly called Honouring, and Dishonouring. To Value a man at a high rate, is to Honour him; at a low rate, is to Dishonour him." T. HobBes, Leviathan 42 (1651).

16. J. Hawes, Lectures AdDRessed to THE Young MEN of HaRTFord and New HAVEN 95 (Hartford 1828).

17. Id. at $95-96$.

18. Id. at 112 . 
also be understood as the result of individual exertion. From this perspective defamation law safeguards "that repute which is slowly built up by integrity, honorable conduct, and right living. One's good name is ... as truly the product of one's efforts as any physical possession." 19 The potential financial importance of a reputation for good character was stressed by Max Weber, who in his travels in the United States observed that qualifying for "admission" to certain voluntary religious sects was "recognized as an absolute guarantee of the moral qualities of a gentleman," a guarantee that immediately translated into "credit worthiness." 20 Benjamin Franklin even went so far as to define "character in terms of the amount of 'credit' a cominunity would extend to a person, based on an estimate of his 'good repute,' his 'affluence,' and his 'felicity." "21 Unjustified aspersions on character can thus deprive individuals of the results of their labors of self-creation, and the ensuing injury can be monetarily assessed.

The concept of reputation as property presupposes that individuals are connected to each other through the institution of the market. The market provides the mechanisn by which the value of property is deternined. The purpose of the law of defanation is to protect individuals within the market by ensurmg that their reputation is not wrongfully deprived of its proper market value. Defaination law should therefore not be concerned with purely private injuries which are independent of the market. Although individuals may attach importance to the way others regard them, a decline in this regard resulting merely in hurt feelings should not be the subject of redress. Thus Starkie notes that defaniation law exists to conipensate "temporal" losses, not "spiritual grievances, which cannot be estimated in money ... [A]nd so, a mere injury to the feelings without actual deterioration of person or property, cannot form an independent and substantive ground of proceeding."22

Underlying the concept of reputation as property is an imphicit in1age of a form of society that I shall call a "market society." Three distinctive features of this image should be eniphasized. First, because the concept views a person as capable of creating his reputation, ${ }^{23}$ it presupposes that no matter what society's present estimation of an individ-

19. Veeder, The History and Theory of the Law of Defamation, 4 CoLUM. L. REV. 33 (1904).

20. Weber, The Protestant Sects and the Spirit of Capitalism, in From MAX WEBER: ESSAYS in Sociology 302, 308 (H.H. Gerth \& C. W. Mills eds. 1958).

21. B. Bledstein, The Culture of Professionalism 134 (1976).

22. T. STARKIE, supra note 14 , at 9.

23. Of course reputation as property, like any other form of property, can, in certain circumstances, be exchanged between persons; it can sometimes be sold and perhaps even inherited. An example would be a corporation that purchases the good will of another. The essential point, however, is that reputation as property can also be the product of individual effort, indeed may ultimately be founded upon individual effort, and that the worth of such reputation is determined by reference to the marketplace. 
ual, he in theory always retains the capacity to work toward the production of a new reputation. In this sense individuals in a market society are understood to possess personal identities that are distinct from and anterior to their social identities. ${ }^{24}$ Individuals are not constituted by the social regard with which they are apprehended by others.

Second, because the concept of reputation as property requires defamation law to protect only those aspects of an individual's reputation that the market can measure, the concept assumes that the worth of a person's reputation will vary with market conditions. Reputation is thus not an absolute, a matter of either honor or dishonor. It is instead envisioned as a smooth and continuous curve of potential value. The legally protected interest in reputation will rise or fall depending upon an individual's productivity and upon fluctuations in market conditions.

Third, the concept of reputation as property presupposes that all persons are equal, in the sense of "the equal subordination of every individual to the laws of the market."25 No person has the right to a reputation other than that created by the evaluative processes of the market, and, conversely, every person enjoys an equal right to enter the market to attempt to achieve what reputation he can.

The concept of reputation as property, together with the image of the market society that it carries within it, can create a powerful and internally coherent account of defamation law. It can explain why the law protects reputation, and what kinds of social evaluation deserve the law's protection. There are aspects of modern defamation law that can be understood only by reference to the concept of reputation as property, as, for example, the fact that corporations and other inanimate entities can sue for defamation. ${ }^{26}$ The concept of reputation as property is so deeply imbedded in our understanding of defamation law that a prominent nineteenth century writer could conclude that in defamation law "the protection is to the property, and not to the reputation. . . . [P]ecuniary loss to the plaintiff is the gist of the action for slander or hibel."27 And in the twentieth century no less a commentator than David Riesman could observe that where, as in the United States, "tradition is

24. See A. Kronman, Max Weber 104 (1983).

25. C.B. MacPherson, The Political Theory of Possessive Individualism: Hobbes TO LOCKE 85 (1962). Many of the characteristics described in the text are similar to those used by MacPherson to describe a "possessive market society." See id. at 53-61.

26. Restatement (Second) of Torts $\$ \S 561-562$ (1977); W. Prosser, D. Dobds, R. Keeton \& D. OWen, Prosser \& Keeton on Torts 779-80 (5th ed. 1984) [hereinafter Prosser \& KEETON].

27. J. Townshend, A Treatise on the Wrongs Called Slander and Libel 108-09 (1877). Almost 100 years earlier James Wilson had noted that "the honour of character is a property, which is, indeed, precious. . . [I]t is a property, which must be purchased." 2 THE WoRKS OF JAMES WILSON 595 (R. McClosky ed. 1967). See Dixon v. Holden, 7 L.R.-Eq. 488, 492 (1869) (A man's reputation "is his property, and, if possible, more valuable than other property.") 
capitalistic rather than feudalistic, reputation is only an asset, 'good will', not an attribute to be sought after for its intrinsic value."28

It is clear, however, that the concept of reputation as property is deeply inconsistent with important doctrines of common law defamation. It cannot explaim so fundamental a doctrine as that a communication must be deemed defamatory before it can support an action. ${ }^{29}$ The common law of defamation will not offer redress for untrue communications that are not defamatory, even if they cause damage to an individual's credit or business opporturities. An example is a communication to the effect that an individual is dead. ${ }^{30}$ The very elementary requirement that liability attach only to defamatory communications can be explained only by reference to a concept of reputation other than that of reputation as property.

The concept of reputation as property also cannot explain the important fact that at common law "harm to reputation was presumed fronı the publication" of a commumication that was a slander per se or libel, and that in a civil suit "the trier of facts could return a substantial verdict for the plaimtiff without any proof of actual harm to reputation."31 The presumption of damages thus puts defamation law in the business of compensating individuals for harms which, from the perspective of reputation as property, may well be nonexistent.

The usual explanation of this "oddity of tort law,"32 which has been called "the nost important single rule in defamation," 33 is "that damage to reputation is recurringly difficult to prove and that requiring actual proof would repeatedly destroy any chance for adequate conipensa-

(per Malins, V.C.). G.S. Bower, A Code of The Law of Actronable Defamation 275 (1908) ("For purposes of the civil law of defamation, reputation is regarded as a species of property.").

28. Riesman, Democracy and Defamation: Control of Group Libel, 42 ColuM. L. REV. 727, 730 (1942). For this reason Riesman concluded that in the United States " $[t]$ he law of libel is consequently unimportant." Id.

29. RESTATEMENT (SECOND) OF TORTS $§ \S 558-559$ (1977).

30. Cohen v. New York Times Co., 153 A.D. 242, 138 N.Y.S. 206 (1912).

31. L. Eldredge, The Law of Defamation $\S$ 95, at 537 (1978). See Melton v. Bow, 241

Ga. 629, 630, 247 S.E.2d 100, 101 (1978), cert. denied, 439 U.S. 985 (1978).

From the fact of the publication of the defamatory matter by the defendant, damage to the plaintiff is said to be 'presumed,' and the jury, without any further data, is at liberty to assess substantial damages, upon the assumption that the plaintiff's reputation has been injured and his feelings wounded.

McCormick, The Measure of Damages for Defamation, 12 N.C.L. REv. 120, 127 (1933).

Townshend viewed the presumption of damages as a "fiction . . . of pecuniary loss." J. TowNSHEND, supra note 27 , at 110 . The common law of defamation did not presume damages if the publication at issue constituted a slander that did not fall within one of the per se categories. See text accompanying notes $40-41$ infra.

32. Gertz v. Robert Welch, Inc., 418 U.S. 323, 349 (1974).

33. Kalven, The Law of Defamation and the First Amendment, in CONFERENCE ON THE ARTS, Publishing and the LAw 12 (1952) 
tion."34 But there are three reasons why this explanation is unconvincing, at least under the concept of reputation as property. First, the presumption of injury in defamation law is irrebuttable. "[T]he fact that defendant can show that no damage whatsoever has occurred will not defeat the action." 35 Simce damages are "conclusively" presumed, ${ }^{36}$ a plaintiff can recover large damages even if he specifically withdraws from the court any claim that his reputation has in fact been damaged ${ }^{37}$ and even if it is established that no one believed the defamatory communication. ${ }^{38}$ The fact that the presumption of general damages is irrebuttable is mexplicable from the standpoint of the concept of reputation as property, and it strongly suggests that the presumption is performing a function quite different than that of merely filling an evidentiary vacuum.

Second, the law of defamation presumes damages only in certain kinds of cases. The common law distinguislies between libel and slander, ${ }^{39}$ and between slander and slander per se. ${ }^{40}$ Damages are presumed only if the communication at issue constitutes slander per se or libel. ${ }^{41}$ While cases that require proof of damages are now relatively rare, they were once viewed as constituting an important part of defamation law. Indeed Starkie observed that "[i]n general . . . it is necessary to prove a specific loss to have been sustained, by the evidence of which a jury is to be guided in assessing pecuniary damages." ${ }^{42}$ Yet there is no reason to believe that im such cases the difficulty in proving actual damage to reputation is in any degree diminished.

34. Gertz, 418 U.S. at 394 (White, J., dissenting); see Dun \& Bradstreet Inc., v. Greenmoss Builders, Inc., I0S S.Ct. 2939, 2946 (1985) (opinion of Powell, J.).

35. I A. Hanson, Libel and Related Torts $\$ 161$ (1969). See Gatiey on Libel aNd SLANDER If 4 (8th ed. 1981); REsTATEMENT (SECOND) OF TORTS $\$ 559$ comment d (1977).

36. Clark v. McClurg, 215 Cal. 279, 284, 9 P.2d 505, 507 (1932); Johnson v. Finance Acceptance Co., 118 Fla. 397, 400-01, 159 S. 364, 365 (1935); Lorillard v. Field Enterprises, Inc., 65 Ill. App. 2d 65, 78, 213 N.E.2d 1, 7 (1965); Baker v. Clark, 186 Ky. 816, 820, 218 S.W. 280, 282 (1920); Matherson v. Marchello, 100 A.D.2d 233, 237, 473 N.Y.S.2d 998, 1002 (1984); Stewart v. Nation-Wide Check Corp., 279 N.C. 278, 284, 182 S.E.2d 410, 414 (1971); Memphis Pub. Co. v. Nichols, 569 S.W.2d. 412, 419 (Tenn. 1978).

37. Time, Inc. v. Firestone, 424 U.S. 448, 460 (1976).

38. Farnum v. Colbert, 293 A.2d 279, 282 (D.C. 1972); Modisette \& Adams v. Lorenze, 163 La. 505, 511, 112 So. 397, 399 (1927); Bonkowski v. Arlan's Department Store, 383 Mich. 90, 97-98, 174 N.W.2d 765, 767 (1970); Herrmann v. Newark Morning Ledger Co., 48 N.J. Super. 420, 44I, 138 A.2d 61, 72 (1958).

39. REsTATEMENT (SECOND) OF TORTS $\$ 568$ (1977). A rough characterization of this distinction is that it corresponds to the difference between written and oral communication. But see id. $\$ 568 \mathrm{~A}$.

40. Id. $\$ \$ 569-574$. Although the common law has at various times recognized different categories of slander per se, it is now ordinarily understood to encompass four kinds of oral communication: those that impute a criminal offense to another; those that impute a loathsome disease; those that impute matters incompatible with another's business, trade, profession, or office; and those that impute serious sexual misconduct. Id. $\S 570$.

41. Id. $\$ \S 558(\mathrm{~d}), 575$.

42. T. STARKIE, supra note 14 , at 9. 
Third, in the closely related tort of injurious falsehood, which historically has been known by such names as "disparagement of property," "slander of goods," or "trade libel," and which is unequivocally addressed to the protection of property interests like chattels, trademarks, copyrights, and patents, the law does not presume dainage from the fact of publication. ${ }^{43} \mathrm{~A}$ plaintiff inust instead earn his dainages by tendering the usual proof of pecuniary loss. ${ }^{44}$ In many cases, particularly where the plaintiff is a corporation, it is difficult to distinguish between defamation and injurious falsehood, since it is not possible to separate defamation of the plaintiff from disparageinent of plaintiff's property or business. ${ }^{45}$ Yet damages will only be presuined if the action is styled as one for defamation. In sucl cases the evidentiary explanation of the presumption of danages is revealed as the fiction that it is.

Inportant and fundainental aspects of defamation law are thus inexplicable from the perspective of reputation as property. To understand them, we inust turn to the analysis of other concepts of reputation.

\section{B. Reputation as Honor}

There is an ancient tradition which views the worth of reputation as incommensurate with the values of the inarketplace. The Bible, for exainple, tells us that "[a] good naine is rather to be chosen than great riches." 46 And Shakespeare observes that a "purse" is merely "trash" when coinpared to the value of a "good naine." 47 The concepts of reputation underlying this tradition are clearly incompatible with the notion of reputation as a form of property.

One strand of this tradition was influential in preindustrial England during the formative years of defamation law. This was the view that reputation was a form of honor. ${ }^{48}$ The concept of honor has many aspects, ${ }^{49}$ but the kind of honor that was inost important for the developinent of defaination law inay be defined as a form of reputation in which an individual personally identifies with the normative characteristics of a

43. See Prosser \& Keeton, supra note 26, at 962-68.

44. RESTATEMENT (SECOND) OF TORTS $§ 633$ (1977).

45. Prosser \& KeEton, supra note 26, at 964-65.

46. Proverbs 22:1.

47. See W. SHAKESPEARE, Othello, supra note 7.

48. See C.L. Barber, The Idea of Honour in the ENGlish Drama: 1591-1700 13 (1957); G.D. SQuibi, The High Court of Chivalry: A Study of THe CiviL LaW in ENGLAND (1959); Fletcher, Honour, Reputation and Local Officeholding in Elizabethian and Stuart England, in Order and Disorder IN EARLY MOdern ENGLAND (A. Fletcher \& J. Stevenson eds. 1985); James, English Politics and the Concept of Honour 1485-1642, PAST \& PRESENT, 1 (Supp. 3, 1978); Marston, Gentry Honor and Royalism in Early Stuart England, 13 J. BRIT. STUD. 21 (1973); O'Malley, From Feudal Honour to Bourgeouis Reputation: Ideology, Law and the Rise of Industrial Capitalism, 15 Soc: J. Brit. Soc. Ass'N. 79 (1981).

49. See Pitt-Rivers, Honor, in 6 INT'L ENCYCLOPEdIA Soc. Scl. 503, 503-11 (1968). 
particular social role and in return personally receives from others the regard and estimation that society accords to that role. ${ }^{50}$ An individual does not earn or create this kind of honor through effort or labor; he claims a right to it by virtue of the status with which society endows his social role. ${ }^{51}$ For example a king does not work to attain the honor of his kingship, but rather benefits from the honor which society attributes to his position. The price of this benefit is that society expects him to aspire to "personify" these attributes and to make them part of his personal honor. 52

The anthropologist John Davis has observed that the "essential characteristics of honour are"

first that it is a system of stratification: it describes the distribution of wealth in a social idiom, and prescribes appropriate behaviour for people at the various points in the hierarchy; it entails acceptance of superordination and subordination. Second, it is an absolute system . . . . Third, it does seem to be characteristic of honour that it is associated with integrity: the whole man is contemplated. ${ }^{53}$

Honor differs from the concept of reputation as property in each of these characteristics. Whereas reputation as property presupposes the equality of all individuals before the marketplace, honor presupposes that individuals are unequal. An individual's honor is but the personal reflection of the status which society ascribes to his social position. Individuals are therefore inherently unequal because they occupy different social roles. It is characteristic of honor that these social roles are hierarchically arranged. Thus Montesquieu theorized that "honor" is the principal "spring" of monarchies, because "it is the nature of honor to aspire to preferments and distinguishing titles," and "[a] monarchical government supposeth . . preeminences, ranks, and likewise a noble descent."

Whereas reputation as property assumes that the value of reputation fluctuates accordimg to individual effort and market conditions, reputation as honor is fixed. Different social positions will be more or less honorific, and within each social position either one will have the honor which is due that position, or one will not and be accordingly dishonored. Honor cannot be converted into a continuous inedium of exchange. It cannot be bought and sold like goodwill, but is instead attached to

50. For a discussion of the relationship between the concept of honor and the nature of status groups, see M. WEBER, supra note 20 , at $186-88$.

51. Pitt-Rivers, Honour and Social Status, in Honour and Shame: THE VAlues of THE Mediterranean 21-22, 35 (J.G. Peristiany ed. 1966).

52. Id. at 22. See J.K. CAMPBELL, Honour and the Devil, in HONOUR AND SHAME: ThE VAlues of THE MEDITERRANEAN, supra note S1, at 149.

53. J. Davis, People of the Mediterranean: AN Essay in Comparative Social ANTHROPOLOGY 98 (1977).

54. MONTESQUiEU, The SPIRIT OF THE LAWS 121-22 (D.W. Carrithers ed. 1977). 
specific social roles. ${ }^{55}$ It can be forfeited by improper behavior, but it cannot be individually created. It is a inatter of either fulfilling or failing to fulfill the requirements of one's social position.

Whereas reputation as property presupposes that individual identity is distinct from reputation, in the sense that an individual can always construct a new reputation, honor is a matter that swallows "the whole man." "The concept of honor implies that identity is essentially, or at least importantly, linked to institutional roles."56 Conversely, "dishonor is a fall froin grace in the most comprehensive sense-loss of face in the community, but also loss of self and separation from the basic norms that govern human life."57

The Purest Treasure mortal times afford

Is spotless reputation; that away,

Men are but guilded loam or painted clay.

A jewel in a ten-times-barr'd chest

Is a bold spirit in a loyal breast.

Mine honour is iny life, both grow in one,

Take honour from me and iny life is done. ${ }^{58}$

The value of honor is the value of a meaningful life, and for that reason its worth cannot be measured by the marketplace. As stated in the report of De Libellis Famosis, one of "the earliest authorities upon the law of libel of any importance," 59 a good name "ought to be more precious" than life itself. ${ }^{60}$

The concept of honor presupposes an inrage of society in which ascribed social roles are pervasive and well established, and in which such roles provide the point of reference both for the ascription of social status $^{61}$ and for the normative standards of personal conduct. The soci-

55. The practice in preindustrial England of buying and selling honorific titles was widely perceived to be disreputable, in large part because it attempted to convert status into money. For example in 1626 the House of Commons complained that the practice " "extremely deflowers the flowers of the Crown; for it makes them cheap to all beholders'; it deprives the Crown of the best and cheapest way of rewarding great public servants, since it brings such rewards into contempt; it makes men pursue money rather than merit; 'It introduceth a strange confusion, mingling the meaner with the more pure and refined metal'; in short, 'It's a prodigious scandal to this nation.' " Quoted and summarized in L. Stone, The Crisis of THe ARISTOCRACy 120 (1965).

56. P. Berger, B. Berger \& H. Kellner, The Homeless Mind: Modernization and CONSCIOUSNESS 90 (1973).

57. Id. at 87. See N. Elias, The Court SOCIETY 95-96 (E. Jephcott trans. 1983).

58. W. Shakespeare, Richard II, act I, scene i, 11. 177-83.

59. 2 J.F. Stephen, A History of THE CRiminal LAW OF ENGLAND 304 (1883).

60. 3 Co. Rep. 254, 255, pt. v, fol. 125, 77 Eng. Rep. 250, 251 (1605). "As the soule is more precious than the bodie; so it is greater offence to take away any mans good name, which refresheth the soule, then to defraude him of his foode, that sustaineth but the bodie." B. RicH, FAuLTES Faults and Nothing Else But Faults 13 (M. Wolfe Scholars' Facsimiles and Reprints ed. 1965) (1606).

61. For a discussion of the concept of ascribed status, see R. LinTON, THE STUdy OF MAN 113-31 (1936). 
ety of preindustrial England had many of these characteristics; ${ }^{62}$ borrowing froin F.M.L. Thompson's description of eighteenth-century England, I shall refer to this kind of social structure as a "deference society."63

Defamation law would operate differently in a deference society than in a market society. In the latter, reputation is a quintessentially private possession; it is created by individual effort and is of importance primarily to those who have created it. Reputation's clain to legal protection is neither greater nor less than the claim to public protection of similar private goods. The preservation of honor in a deference society, on the other hand, entails more than the protection of inerely individual interests. Since honor is not created by individual labor, but instead by shared social perceptions that transcend the behavior of particular persons, honor is "a public good, not inerely a private possession." ${ }^{4}$ An insult to the king involves not only injury to the king's personal interests, but also damage to the social status with which society has invested the role of kingship.

The protection of honor thus involves the inaintenance of "the consensus of the society with regard to the order of precedence."65 To serve this function, defamation law inust define and enforce the ascribed status of social roles. This function can be perceived in the early common law, in which words that "would not be actionable in the case of a coininon person, yet when spoken in disgrace of ... high and respectable characters ... amount to an atrocious injury." 66 The function was epitomized in the law of seditious libel, which pumished as a crime any speech "that inay tend to lessen [the King] in the esteein of his subjects, may weaken his governinent, or may raise jealousies between hin and his people."67

62. See H. Perkin, The Origins of Modern English Society 1780-1880 24-25 (1969); L. STONE, supra note 55 , at 21. (1963).

63. F.M.L. Thompson, ENglish LANDEd Society in the Nineteenth Century 7, 23

64. Bellah, The Meaning of Reputation in American Society, 74 CALIF. L. Rev. 743, 745 (1986). Consider, in this light, Francis Holt's early treatise on libel law, which contains eleven chapters describing different kinds of libel, ranging from "Libels against the Christian Religion" to "Libels against the King's Government." F. HolT, THE LAW OF LiBEL (London 1816). Only one of these eleven chapters concerns "Libels against Private Persons."

65. J. Pitt-Rivers, supra note 51, at 38.

66. W. BlaCKSTONE, supra note 10, at 123. See F. HolT, supra note 64, at 90: "The offence of libel and slander is proportionately more criminal as it presumes to reach persons to whom special veneration is due. The diminution of their credit is a public mischief, and the state itself suffers in their becoming the objects of scorn ...."

67. W. Blackstone, supra note 10, at 123; see W.B. Odgers, A Digest of THE LAW of LIBEL AND SLANDER 479-98 (4th ed. 1905). In 1724 Sergeant William Hawkins could summarize the law of defamation as reaching its apex in the crime of seditious libel:

Nor can there be any Doubt, but that a Writing which defames private Persons only, is as much a Libel as that which defames Persons intrusted with a Publick Capacity, inasmuch as it manifestly tends to create ill Blood, and to cause a Disturbance of the Publick Peace; However, it is certain, That it is a very high Aggravation of a Libel that it tends to scandalize the Government, by reflecting on those who are intrusted with the 
Seditious libel protected "not only the royal family and other dignitaries in person, but also certain groups which symbolize or represent the 'State.' "68

In defining and enforcing the ascribed status of social roles, defaination law is "authoritative," 69 in the sense that it speaks with the full force of public power. This ineans that in a deference society defaination law has the potential to be used either as a potent inethod for reaffirming the importance to the whole society of the status of particular social roles, or as an instrument for the forceful imposition of such status. The tension between these two functions is illustrated by the enactinent of Fox's Libel Act in $1792 .{ }^{70}$ Prior to the Act, judges in eighteenth-century England had atteinpted strictly to confine the discretion of juries in criminal trials for seditious libel. Judges decided whether the communication at issue was seditious and whether it had been published with criminal intent. ${ }^{71}$ Virtually all that was left to juries was the einpty task of determining whether the defendant had in fact published the offending communication. ${ }^{72}$ The Act was a "moinentous change in the law of libel,"73 giving juries the power to return a general verdict and hence to exercise their power of nullification. ${ }^{74}$ In essence, therefore, the Act ensured that judges, as officers of the crown, could not use the law of seditious hibel to impose a view of ascribed hierarchical status not sliared by the community at large.

From the perspective of an individual who has been dishonored by a libel or slander, the function of defamation law carmot be simply to provide coinpensation for injuries "capable of pecuniary admeasurement."75 The loss of honor is a loss of status and personal identity; the value of a good name, which "ought to be more precious" than he, ${ }^{76}$ can scarcely be comprehended by pecuniary damages. Instead the essential objective of defamation law inust be conceived as the restoration of honor. I shall use the term "vindication" to refer to the process by which honor is

Administration of Publick Affairs, which doth not only endanger the Publick Peace, as all other Libels do, by stirring up the Parties immediately concerned in it to do Acts of Revenge, but also has a direct Tendency to breed in the People a Dislike of their Governors, and incline them to Faction and Sedition.

W. Hawkins, a Treatise of the Pleas of the Crown 194 (2d ed. 1724).

68. Riesman, supra note 28 , at $735-36$.

69. C.B. MACPherson, supra note 25 , at 49; see Pitt-Rivers, supra note 49, at 504.

70. See J.F. STEPHen, supra note 59, at 319-47.

71. See Green, The Jury, Seditious Libel, and the Criminal Law, in JURIES, Libel \& Justice:

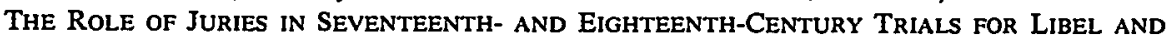
SLANDER 40-41 (1984).

72. L. Levy, Emergence of A Free Press 11-12 (1985).

73. T. Plucknetr, A CONCISE History OF THE COMmon LaW 500 (5th ed. 1956).

74. Green, supra note 71 , at $44-45$.

75. T. STARKIE, supra note 14 , at $\mathrm{xx}$.

76. De Libellis Famosis, 3 Co. Rep. 254, 255, pt. v, fol. 125, 77 Eng. Rep. 250, 251 (1605). 
restored. Vindication should be understood as the mirror image of the "denunciation of wrong doing" "which occurs in the criminal law. The conviction and punishment of a criminal defendant is in effect a "status degradation ceremony" in which the defendant "becomes in the eyes of his condemners hiterally a different and new person."78 The vindication of the honor of a bibel victim can be thought of as the converse, as a "status rehabilitation ceremony."

In order to understand how defaination law can vindicate honor, it must be recalled that at traditional common law a libel victim was given a choice of "two remedies; one by indictment and another by action."79 If the person elected to proceed by way of criminal prosecution, the truth or falsity of the bibel was deemed iminaterial, ${ }^{80}$ and the defendant was "not allowed to alledge the truth of it by way of justification." the hibel victim achieved vindication not by disproving the libel, but rather by pumishing the hibeller. This is consistent with the earliest ineanmg of "vindication," which is "the action of avenging or revenging."82 There is a clear analogy between the traditional coinmon law of criminal hibel and the "Code of Honor" under which gentlemen duelists sought to "avenge insults" and thereby achieve "the restoration of wounded honor."83 As the old saw would have it, "The laundry of honor is only

77. Royal Commission on Capital Punishment, Minutes of Evidence, Ninth Day, 207 (Dec. 1, 1949) (Memorandum Submitted by the Rt. Hon. Lord Justice Denning) reprinted in S. Kadish, S. Schulhofer \& M. Paulsen, Criminal Law and its Processes: Cases and MAterials 190 (4th ed. 1983).

78. Garfinkel, Conditions of Successful Degradation Ceremonies, 61 AM. J. Soc. 420, 420-21 (1956).

79. W. BLACKSTONE, supra note 10 , at 125 . See F. Holt, supra note 64 , at 241 . A person who had been slandered did not have the option of proceeding by way of criminal indictment, unless he was "one of the great men of the realm," in which case the slander was deemed Scandalum Magnatum and punishable by criminal prosecution. T. STARKIE, supra note 14, at 145-47. For a rare example of the use of Scandalum Magnatum in America, see J. BENTON JR., A Notable Libel Case: The Criminal Prosecution of Theodore Lyman Jr. by Daniel Webster 35 (1904).

80. See De Libellis Famosis, 3 Co. Rep. 254, 255, pt. v, fol. 125, 77 Eng. Rep. 250, 251 (1605) ("It is not material whether the libel be true.").

81. W. Blackstone, supra note 10, at 126 (footnote omitted). For a discussion of the American cases, see 2 J. Kent, Commentaries on AMERICAN LAw 18-24 (2d ed. New York 1832). In the view of the early common law, "the greater the truth, the greater the libel." Riesman, supra note 28 , at 735 .

82. 8 OXFORD ENGLish Dictionary 496 (James Murray ed. 1910). In modern English this sense remains present in the word "vindictive," which stems from the same root as vindication.

83. M. Hindus, Prison and Plantation 42-48 (1980). See B. Mandeville, An EnQuiry into the Origin of Honour 64-75 (London 1732); W.O. Stevens, Pistols at Ten Paces: The StORY OF THE CODE OF HONOR IN AMERICA (1940); Andrew, The Code of Honor and its Critics: The Opposition to Duelling in England, 1700-1850, 5 Soc. HIST. (U.K.) 409 (1980).

In his Principles of Penal Law, Jeremy Bentham gave considerable thought to the question of what legal "remedies for offences against honour" could create the "honorary satisfaction" provided by "the practice of duelling." I THE WORKS OF JEREMY BENTHAM 376-80 (1859). Bentham listed 12 different punishments for such offenses, ranging from "[t]he offender kneeling before the party 
bleached with blood." 84

If the libelled person elected to proceed by way of civil action, however, the situation was quite different. The defendant could not be punished, but only compelled to pay damages. Although the stated purpose of the award of damages was to permit "the plaintiff ... to recover by way of compensation,"85 the concept of reputation as honor would require these damages also to be understood as part of the process by which the plaintiff's honor was vimdicated. ${ }^{86}$ Thus in an early case in which a defendant had said of an Enghish Lord that he was "an unworthy man, and acts against law and reason," the jury awarded four thousand pounds in damages to the plaintiff not, it was said, "that he was damnified so much, but that he might have the greater opportumity to shew himself noble in the remitting of them."87

Analysis is further complicated by the fact that truth was (and is) a complete defense to the civil tort of libel..$^{88}$ Thus the relief provided by the civil action could not be simply vindication in the primitive sense of "avenging," but rather in the inore modern sense of "justifying." The issue of truth shifts inquiry away from the impersonal attributes of social roles, which caimot be true or false, and toward the particular conduct of the mdividuals who occupy those roles. In contrast to the criminal rem-

injured," to "[e]mblematical masks, with a snake's head in cases of fraud - - with a Magpie's or a Parrot's head in cases of temerity." Id. at 381. The remedies were to "be adapted to the gravity of the cases, and furnish suitable reparations to the different social distinctions; for it is not proper to treat in the same manner an insult offered to a common person and to a magistrate, to an ecclesiastic and to a military man, to a young and to an old person." Id. The purpose of the remedies was to humiliate the offender and to "furnish to the injured party actual pleasures, and pleasures of remembrance, which would compensate for the mortification of the insult." Id. The injured party would thus receive "vindictive satisfaction," which Bentham defined as "a pleasure of vengeancc." Id. at 382-83. Bentham believed that insofar as the law provided such "measures suited to the protection of honour, the use of duels will diminish; and they will cease entirely, when these honorary satisfactions agree exactly with opinion, and are faithfully administered." Id. at 382.

84. "La lessive de l'honneur ne se coule qu'au sang." Pitt-Rivers, supra note 51, at 25 (footnote omitted); see id. at 24-31.

85. Lord Townsend v. Hughes, 86 Eng. Rep. 994, 994 (1677).

86. "[C]ivil actions for slander and libel," like criminal actions, "developed in early ages as a substitute for the duel." I. BRANT, The BILl of Rights: Its ORIGIN AND Meaning 502 (1965); see P.F. CARTER-RucK, supra note 7, at 39 (1972).

87. Lord Townsend v. Hughes, 86 Eng. Rep. at 994 (1677). Cf. Staves, Money for Honor: Damages for Criminal Conversation, in 11 Studies IN EIghteenth-Century Culture 279 (H. Payne ed. 1982).

88. See Holdsworth, Defamation in the Sixteenth and Seventeenth Centuries, 41 L.Q. REV. 13, 28 (1925). There is some ambiguous authority for the conclusion that in the early days of the common law truth was not a defense to a civil action for libel. See Ray, Truth: A Defense to Libel, 16 MiNN. L. REv. 43, 49-50 (1931). There are also some relatively modern cases holding that truth is not a complete defense. See, e.g., Hutchins v. Page, 75 N.H. 215, 72 A. 689 (1909). For an examination of these cases, see Franklin, The Origins and Constitutionality of Limitations on Truth as a Defense in Tort Law, 16 STAN. L. REV. 789 (1964).

89. "The action of making, proving, or accounting just." 8 OXFORD ENGLISH DICTIONARY 496 (James Murray ed. 1910). 
edy, in which truth was irrelevant and the focus of the proceeding was therefore clearly and narrowly on the defendant's affront to the honorific status of the plaintiff's role, the focus of the civil proceeding was expanded to include the possible derelictions of the plaintiff. Since an individual could be dishonored for failing to he up to the requireinents of his social role, the plaintiff could be required to demonstrate that he had not acted dishonorably before being entitled to receive civil damages.

The concept of reputation as honor is consonant with aspects of defaination law that are difficult to understand from the perspective of reputation as property. For example, the common law distinction between defamatory and nondefamatory communications, which in a market society would leave some actual injuries inexplicably uncompensated, can be conceptualized as a method of distinguishing between those commumications that are relevant to the question of honor, and those that are not. Similarly, the common law presumption of damages, which in a market society is simply an undeserved windfall to the plaintiff, can be conceived as empowering juries to pursue the "noncompensatory" 90 end of vindicating the plaintiff's honor in the community.

The kind of deference society presupposed by the concept of reputation as honor could not be said to have existed in anything like a pure form in preindustrial England. ${ }^{91}$ Even as Coke was reporting De Libellis Famosis, Shakespeare, in the accents of King Lear's darkest vision, had seen the beggar run from the farmer's dog, and had beheld "the great image of authority - a dog's obeyed in office."92 This dissociation of the person from the office is incompatible with the very premises of a deference society. It is in fact inore characteristic of our orwn social world, dominated as it is by a rational legal authority in which bureaucratic office is defined precisely by its contrast to the private identity of officeholders. ${ }^{93}$ If in a deference society an attack upon the person of the king was equivalent to an attack on the institution of monarchy, we are now inore likely to distinguish between an attack on the president and an attack on the institution of the presidency.

As this example illustrates, however, we still have a lingering sense that roles and individuals are interdependent. ${ }^{94}$ De Tocqueville, cominenting on the demise of honor in the United States, observed that "the

90. Anderson, Reputation, Compensation, and Proof, 25 WM. \& MARY L. REv. 747, 750 (1984).

91. See, e.g., C. Hill, The World Turned Upside Down: Radical ideas During the ENGLISH REVOLUTION 32-45 (1972).

92. W. SHAKESPEARE, KING LEAR, act IV, scene vi, 11. 152-56.

93. See generally M. WEBER, supra note 11, at 217-23.

94. See, e.g., Youngstown Sheet \& Tube v. Sawyer, 343 U.S. 579, 634 (1952) (Jackson, J., concurring) ("The opinions of judges, no less than executives and publicists, often suffer the infirmity of ... confounding the permanent executive office with its temporary occupant."). 
dissimilarities and inequalities of men gave rise to the notion of honor; that notion is weakened in proportion as these differences are obliterated, and with them it would disappear."95 Our contemporary attitude toward honor is for this reason bound up with our commitınent to egalitarianism. In soine institutions, like the military, egahtarian ideals play a relatively small role, and consequently the concept of personal honor, as defined by a hierarchical structure of rigidly defined social roles, remains of great importance. ${ }^{96}$ In other institutions, like the profession of medicine, we remain genuinely ambivalent whether the reputation of a doctor steins solely froin her achievements, or whether it inheres in part in the magical status of simply being a physician. As these illustrations suggest, the concept of reputation as honor is not merely an important analytic tool for understanding the early common law of criminal hbel, and perhaps also the development of the civil side of the tort, but it may also have significant implications for understanding the ways in which our own law of defamation is actually practiced.

\section{Reputation as Dignity}

When the Umited States Supreme Court attempts to characterize the nature of a state's interest in protecting reputation, it frequently relies upon a passage in Justice Stewart's concurring opimion in Rosenblatt $v$. Baer: ${ }^{97}$

The right of a man to the protection of his own reputation from unjustified invasion and wrongful hurt reflects no more than our basic concept of the essential dignity and worth of every human being - a concept at the root of any decent system of ordered liberty. The protection of private personality, like the protection of hife itself, is left primarily to the individual States under the Ninth and Tenth Amendments. But this does not inean that the right is entitled to any less recognition by this Court as a basic of our constitutional system.

The rhetorical power of the passage is undeniable. It has proved enormously influential, ${ }^{98}$ and can fairly be characterized as an authentic con-

95. II A. DE TOCQUeVILle, DemoCRACY IN AMERICA 255 (H. Reeve trans. 1945).

96. See G. Best, Honour Among Men and Nations (1982); M. Feld, The Structure OF VIOLENCE: ARMEd ForCes AS SOCIAl SySTEMS 98-102 (1977); R. Gabriel, To SERVE with HONOR (1982); M. JANOWITZ, THE Professional SOldier 215-32 (1960).

97. 383 U.S. 75, 92 (1966) (Stewart, J., concurring). See Philadelphia Newspapers, Inc. v. Hepps, 106 S. Ct. 1558, 1562 (1986); id. at 1566-67 (Stevens, J., dissenting); Dun \& Bradstreet, Inc. v. Greenmoss Builders, Inc., 105 S. Ct. 2939, 2945 (1985) (opinion of Powell, J.); id. at 2951 (White, J., concurring); id. at 2964 n.16 (Brennan, J., dissenting); Time, Inc. v. Firestone, 424 U.S. 448, 471 (1976) (Brennan, J., dissenting); Gertz v. Robert Welch, Inc., 418 U.S. 323, 341 (1974); id. at 402 (White, J., dissenting); Rosenbloom v. Metromedia, Inc., 403 U.S. 29, 48 (1971) (opinion of Brennan, J.); $i d$. at 78 (opinion of Marshall, J.).

98. See, e.g., Idaho Norland Corp. v. Caelter Indus., 509 F. Supp. 1070, 1072 (D. Col. 1981); Bose Corp. v. Consumers Union, 508 F. Supp. 1249, 1270 (D. Mass. 1981), rev'd, 692 F.2d 189 (1st Cir. 1982), aff'd, 466 U.S. 485 (1984); Martin Marietta Corp. v. Evening Star Newspaper, 417 F. 
temporary expression of common law understanding of the law of defamation.

The passage, however, appears to rest on a paradox, for it is not immediately clear how reputation, which is social and public, and which resides in the "common or general estimate of a person," can possibly affect the "essential dignity" of a person's "private personality." The gulf that appears to separate reputation from dignity can be spanned only if defamation law contains an implicit theory of the relationship between the private and public aspects of the self.

Precisely such a theory was developed by the founders of the symbohic interactionist school of American sociology, Charles H. Cooley ${ }^{99}$ and George Herbert Mead. ${ }^{100}$ Mead in particular developed a detailed and persuasive account of the interdependence of individual personality and general social perspectives. For Mead the image of the game was of particular significance. In learning a game, a child cannot simply study one role, like that of a third baseman, but must instead come to understand all the different roles that comprise the game, together with their relationship to each other. Only by thus internalizing the perspectives of all the game's participants can the child learn to engage in the common endeavor that is baseball. In a similar way a person learns how to live in a society by understanding the different roles by which it is comprised. The internalization of these various perspectives is what constitutes an individual's identity:

The game is then an illustration of the situation out of which an organized personality arises. In so far as the child does take the attitude of the other and allows that attitude of the other to determine the thing he is going to do with reference to a common end, he is becoming an organic member of society. He is taking over the morale of that society and is beconing an essential menber of it. ...

Supp. 947, 955 (D.D.C. 1976); Rancho La Costa, Inc. v. Superior Court, 106 Cal. App. 3d 646, 655, 165 Cal. Rptr. 347, 353 (1980), cert. denied, 450 U.S. 902 (1981); Holter v. WLCY T.V., Inc., 366 So. 2d 445, 451 (Fla. Dist. Ct. App. 1978); Sindorf v. Jacron Sales Co., 27 Md. App. 53, 341 A.2d 856, 877 (1975), aff'd, 276 Md. 580, 350 A.2d 688 (1976); Stone v. Essex County Newspapers, Inc., 367 Mass. 849, 851, 330 N.E.2d 161, 168 (1975); Cefalu v. Globe Newspaper Co., 8 Mass. App. Ct. 71, 73, 391 N.E.2d 935, 938 (1979), cert. denied, 444 U.S. 1060 (1980); Jadwin v. Minneapolis Star and Tribune Co., 367 N.W.2d 476, 483 (Minn. 1985); Hyde v. City of Columbia, 637 S.W.2d 251, 270 n.25 (Mo. Ct. App. 1982), cert. denied, 459 U.S. 1226 (1983); Anton v. St. Louis Suburban Newspapers, Inc., 598 S.W.2d 493, 498 (Mo. Ct. App. 1980); Canino v. New York News, Inc., 96 N.J. 189, 196-97, 475 A.2d 528, 532 (1984); Maressa v. New Jersey Monthly, 89 N.J. 176, 201, 445 A.2d 376, 389 (1982), cert. denied, 459 U.S. 907 (1982); Schermerhorn v. Rosenberg, 73 A.D.2d 276, 283, 426 N.Y.S.2d 274, 281 (1980); Greenberg v. CBS, Inc., 69 A.D.2d 693, 700, 419 N.Y.S.2d 988, 991 (1979); Rutt v. Bethlehems' Globe Publishing Co., 335 Pa. Super. 163, 185, 484 A.2d 72, 83 (1984).

99. See C. Cooley, The Two Major Works of Charles H. Cooley: Social Organization, Human Nature and the Social Order (1956).

100. See G.H. MEAd, Mind, SelF, ANd Society (1934). 
What goes to make up the organized self is the organization of the attitudes which are common to the group. A person is a personality because he belongs to a community, because he takes over the institutions of that commumity into his own conduct. He takes its language as the medium by which he gets his personahity, and then through a process of taking the different roles that all the others furnish he comes to get the attitude of the members of the commumity. Such, in a certain sense, is the structure of a man's personality. ... . The structure, then, on which the self is built is this response which is common to all, for one has to be a member of a community to be a self. ${ }^{101}$

Erving Goffman, the most influential modern writer in the symbolic interactiomist tradition, has noted that the socialization process described by Mead should not be understood as having a definite terminus, a point at which an mdependent and mature self emerges as if from a chrysalis. Identity is rather contmuously being constituted through social interactions. ${ }^{102}$ For Goffman these interactions take the form of rules of "deference and demeanor."103 Rules of deference define conduct by which a person conveys appreciation "to a recipient of this recipient, or of something of which this recipient is taken as a symbol, extension, or agent."104 Rules of demeanor define conduct by which a person expresses "to those in his immediate presence that he is a person of certain desirable or undesirable qualities."105 Rules of deference and demeanor constitute "rules of conduct which bind the actor and the recipient together" and "are the bindings of society."106 By following these rules, individuals both confirm the social order im which they live and constitute "ritual" and "sacred" aspects of their own identity. ${ }^{107}$ The price of this process, however, is that each "individual must rely on others to complete the picture of him of which he himself is allowed to paint only certain parts."

Each individual is responsible for the demeanor image of hiniself and the deference iniage of others, so that for a complete man to be expressed, individuals inust hold hands in a chain of ceremony, each giving deferentially with proper demeanor to the one on the right what will be received

\footnotetext{
101. Id. at 159, 162; see id. at 152-64.

102. E. GOFFMAN, INTERACTION RITUAL 84-85 (1967).

103. Id. at 47.

104. Id. at 56 .

105. Id. at 77 .

106. Id. at 90 .

107. Id. at 91. In this formulation Goffman was influenced by Emil Durkheim:
}

Morality would no longer be morality if it had no elements of religion. . . . The respect which we have for the human being is distinguishable only very slightly from that which the faithful of all religions have for the objects they deem sacred. This characteristic, sacredness, can be expressed ... in secular terms. ... respect.

... Society has consecrated the individual and made him pre-eminently worthy of

E. Durkheim, Sociology ANd Philosophy 69, 72 (D. Pocock trans. 1953). 
deferentially from the one on the left. While it may be true that the individual has a umique self all his own, evidence of this possession is thoroughly a product of jomt ceremonial labor, the part expressed through the individual's demeanor being no more significant than the part conveyed by others through their deferential behavior toward him. ${ }^{108}$

Goffman's account provides a theory for connecting the law of defamation to the concept of dignity. Dignity, after all, is a ritual and ceremomal aspect of the self that we associate with the self's integrity, ${ }^{109}$ which is to say with its completeness. Dignity can only be confirmed by the respect that is its due. ${ }^{10}$ Yet in Goffman's view dignity is always at risk, smce in any social transaction the "chain of cereinony" may be broken, and hence a "complete man" may fail to be socially constituted. In this way our own sense of intrinsic self-worth, stored in the deepest recesses of our "private personahty," is perpetually dependent upon the ceremonial observance by those around us of rules of deference and deineanor. The law of defamation can be conceived as a method by which society pohices breaches of its rules of deference and deineanor, thereby protecting the dignity of its members. When rules of deference and demeanor are embodied in speech, and hence are subject to the law of defaniation, I shall call them "rules of civility."

A preliminary objection to this concept of reputation as dignity is that defamation law will not impose liability for breach of a civility rule unless there has been a "publication to a third party,"111 whereas Goffman makes clear that rules of deference and demeanor are especially characteristic of face-to-face interactions. If the function of defaniation law is to protect individual dignity, and if individual dignity can be coinpromised by the violation of civihty rules in face-to-face interactions, ${ }^{12}$ it is not clear why defamation law refuses to impose liability in such situations.

The response to this objection requires us to probe somewhat more

108. E. GofFMAN, supra note 102 , at $84-85$.

109. See Pritchard, Human Dignity and Justice, 82 ETHICs 299, 300-02 (1972).

110. See, e.g., Spiegelberg, Human Dignity: A Challenge to Contemporary Philosophy, 9 PHIL. F. (Nos. 1/2) 39, 58-61 (March 1971); Edel, Humanist Ethics and the Meaning of Human Dignity, in Moral Problems IN CONTEMPORARY SOCIETY (P. Kurz, ed. 1969); E. DuRKheIM, supra note 107, at 89; A. GUTMANN, LibERAL EQUality 18 (1980).

111. RESTATEMENT (SECOND) OF TORTS $\$ 558(b)$ (1977).

112. This is no doubt the basis of Alexander Bickel's observation that there is "a kind of cursing, assaultive speech that amounts to almost physical aggression, bullying that is no less punishing because it is simulated." A. BICKEL, THE MORALITY OF CONSENT 72 (1975). In this regard it is fascinating to note that the Anglo-Saxon law from which common law defamation evolved "was particularly concerned with insulting words addressed by one person to another." $T$. PluckneTT, supra note 73, at 483 . The requirement that the communication be published to a third party emerged only gradually. Id. at 484 . 
deeply into the relationship between civility and dignity. Goffinan notes that breaking a rule of conduct creates an ambiguous situation, for

two individuals run the risk of becoining discredited: one with an obligation, who should have governed himself by the rule; the other with an expectation, who should have been treated in a particular way because of this governance. Both actor and recipient are threatened. ${ }^{113}$

In a purely dyadic exchange, the breach of a rule of civility will have equivocal significance, because it is not clear whether the dignity of the recipient or the social competence of the actor has been impaired. When the breach occurs in the presence of third parties, however, the audience is im effect imvited to choose between these two interpretations. If the audience sides with the actor, the recipient will be discredited and stigmatized ${ }^{114}$ as a person unworthy of being treated with civility; in effect he will be subject to "exclusion froin belonging as a respected and responsible"115 meinber of society.

The dignity that defamation law protects is thus the respect (and self-respect) that arises from full membership in society. Rules of civility are the means by which society defines and maintains this diginity. Conversely, rules of civility are also the means by which society distinguishes members from nonmembers. Persons who are socially acceptable will be included within the forms of respect that constitute social diguity; persons who are stigmatized as deviants will be excluded. The maintenance of such social boundaries is an important method by which societies "develop an orderly sense of their own cultural identity" and hence preserve "the stability of social life." 116 Imphicit im the concept of reputation as dignity, therefore, is the potential for a dual function for defamation law: the protection of an individual's interest in dignity, which is to say his interest in being included within the forms of social respect; and the enforcement of society's interest in its rules of civility, which is to say its interest in defining and maintaiming the contours of its own social constitution. ${ }^{117}$

113. E. GofFMAN, supra note 102 , at 51 .

114. In Goffman's view, to stigmatize someone is to view that person in a way that is "deeply discrediting." E. Goffman, Stigma: Notes on the Management of SPOILEd IDENTITY 3 (1963).

115. Karst, Paths to Belonging: The Constitution and Cultural Identity, 64 N.C.L. Rev. 303, 323 (1986).

116. K. ERikson, Wayward Puritans: A Study in the Sociology of Deviance 13 (1966); see E. Durkheim, The Division of LABOR IN SocieTy 108-09 (G. Simpson trans. 1933).

117. Gossip is also a means by which communities (informally) enforce communal norms, and anthropologists view such gossip as "part of the very blood and tissue" of "community life," and a central mechanism by which a community is "held together and maintains its values." Gluckman, Gossip and Scandal, 4 Current ANTHropology 307, 308 (1963). Gossip has the power of "interpreting a community to itself." P.M. SPACKs, GossIP 231 (1985). See Zimmerman, Requiem for a Heavyweight: A Farewell to Warren and Brandeis's Privacy Tort, 68 CoRN. L. REV. 291, 326-37 (1983). 
What it means for the law to perform the first of these functions, the protection of individual dignity, is by no means clear. Dignity is not like property, for dignity is not the result of individual achievement and its value cannot be measured in the marketplace. It is instead "essential" and intrimsic in "every human being." "118 It is inaccurate, therefore, to speak of defamation law as "compensating" for the loss of dignity. Dignity cannot be restored through money damages. ${ }^{119}$ The jury which refused to award compensatory damages to a plaintiff expelled froin Post 12 of the Pohish Army Veterans Association because of an accusation of embezzlement illustrates the point. The jury sent the following written note to the Court:

He who steals my purse, steals trash; but, he who steals my reputation steals my life. Therefore, as ... jurors we feel that no amt. of gold or silver can compensate for a man's reputation \& if Mr. Laniecki [the plaintiff] is publically [sic] cleared and reinstated into (his) Post 12, or the Post of his choice this would be reward enough. We also wish to give nothing for hibel, but grant $\$ 5000$ for punitive damages. ${ }^{120}$

It is also impossible to conceive of dignity as being "vindicated" by a duel or by the early procedures of criminal defamation. Methods that have been consonant with the restoration of honor, therefore, do not seem consistent with our conception of dignity.

What it means to protect dignity is of course dependent upon what it means to lose dignity. If defamation law protects against the loss of dignity that occurs when an individual is potentially excluded from the einbrace of a commumity's rules of civility, then, from the plaintiff's point of view, protection of dignity must imply a confirmation of meinbership $\dot{n}_{1}$ that commumity. Defamation law is an excellent vehicle for that confirmation, because it provides an occasion for a court to resolve the ambignity created when rules of civility are violated. A defaination trial can from this perspective be viewed as an arena in which the parties are free to present "conipeting interpretations of behavior":121 the plaintiff contending that the defamation should be explained by the social incompetence and inappropriate behavior of the defendant; the defendant urging that the lack of respect implied by the defaination should be understood as justified by the plaintiff's conduct. The plaintiff's dignity is rehabilitated if the court authoritatively determines that the defend-

118. Rosenblatt v. Baer, 383 U.S. 75, 92 (1966) (Stewart, J., concurring).

119. See M. Ignatieff, The Needs of Strangers: an Essay on Privacy, Solidarity, and the Politics of Being Human 13-14 (1984).

120. Laniecki v. Polish Army Veterans Ass'n, 331 Pa. Super. 413, 422, 480 A.2d 1101, 1105 (1984) (footnote omitted).

121. Lewis, Defamation: Reputation and Encounter, in Friedman/Rehbinder (Hrsg.), ZUR SOZIOLOGIE DES GERICHTSVERFAHRENS, JAHRBUCH FUR REChTSSOZIOLgIE UND RECHTSTHEORIE, Band 4, 278. 
ant's departure from the rules of civility was unjustified. In effect the court, speaking for the community at large, designates the plaintiff as worthy of respect, thereby confirming his membership within the community. I shall refer to this process by which dignity is confirmed as one of "rehabilitation."

The issue of truth is essential to a plaintiff's rehabilitation, for to succeed in a defamation suit he must persuade a court of the trutl of his mterpretation of events. If he fails in this task and tlie court agrees witl the defendant's interpretation, the plaintiff's efforts will result in an authoritative confirmation of his own stigma. ${ }^{122}$ In either case the defamation trial will demarcate the boundaries of community membership. For this reason it is tempting to view the second function of defamation law, the enforcement of a commumity's rules of civility, as simply the mirror image of the first, the protection of individual digmity. But this would be a mistake. Protecting individual dignity is a matter of defending purely private imterests, whereas enforcing rules of civility is a matter of safegnarding tlie public good inherent in the maintenance of commumity identity.

The two functions are tlius analytically distinct, and the sliape of common law defamation clearly indicates that the protection of the public good is an independent and important objective. This can be seen, for example, in the common law presumption of damages. If one distinguishes between the common law's refusal to make damages an element of the cause of action for libel and its conclusive presumption of damages, it is evident that the former is consistent with the purpose of rehabilitation, since requiring a sliowmg of damages would leave without redress victims of hibel who had suffered no material injury. But the irrebutable presumption of damages does not follow from the purpose of rehabilitation, since dignity is not restored througli a process of compensation. The most plausible imterpretation of the presumption, therefore, is that it serves to maintain community identity, since it creates a license for juries to sanction defendants who trespass beyond the bounds of propriety.

The objective of maintaining community identity is also evident in those cases in which the common law enforces rules of civility even when individual dignity is not in fact at risk. Thus an action for defamation

122. David Hooper notes that "[t]here are two classic examples of the perils of libel actions":

In the first, the plaintiff sued for slander when he was called a highwayman. He lost and was arrested when he was leaving the court, tried on a charge of being a highwayman and hanged at Newgate. In the second Oscar Wilde sued the Marquess of Queensberry ... for his notice about Oscar Wilde 'posing as a sodomite' .... Wilde prosecuted, lost, and was later tried himself and sent to prison for two years.

D. Hooper, Public Scandal, Odium and Contempt: AN Investigation of Recent Libel CASES 23 (1984). 
will lie even if a defendant can demonstrate that the defamatory statement was not "believed by those to whom it was published."123 Moreover under traditional common law rules a defendant could not defeat an action for defamation even by proving that the plaintiff was already such an outcast from the community that he had no reputation to lose. ${ }^{124}$ Evidence of a plaintiff's poor reputation was admissible only in mitigation of dainages. ${ }^{125}$

The common law takes its function of maintaining community identity so seriously that it will refuse to protect individual dignity if it determimes that a particular commumity is not wortlyy of legal support. This is illustrated by the case of Connelly v. McKay, ${ }^{126}$ in which the plaintiff, who maintained a service station and rooming house primarily patronized by interstate truck drivers, alleged that he had been slandered by a statement that he was informing the Interstate Cominerce Commission of the names of truck drivers who were violating ICC rules. The plaintiff claimed that the slander had resulted in damage to his business. It was clear that his reputation, considered as property, had been adversely affected. It was also clear that the slander alleged conduct that was heinous within the community of interstate truckers, and hence that the plamtiff's dignity as a member of that community was at risk. Nevertheless the court refused to enforce the plaintiff's claim, saying that an allegation "of giving information of violations of the law to the proper authorities" could not "constitute a foundation upon which to build an action for slander." 127

In essence the court's decision was that the law of defaination should not be used to maintain the kind of deviant coinmunity constituted by the civility rules of interstate truckers, even though a person's dignity within that community was clearly at issue. Connelly is of course an extreme case, ${ }^{128}$ but it is a particularly clear example of a more subtle problein that defamation law must constantly face: the determination of

123. GATLEY ON LIBEL AND SLANDER, supra note 35, at ๆ 4. "If words are used which impute discreditable conduct to my friend, he has been defamed to me, although I do not believe the imputation, and may even know it is untrue." Hough v. London Express Newspapers, Ltd., [1940] 2 K.B. 507, 515 (per Goddard, L.J.). See Morgan v. Odhams Press Ltd., [1971] 1 W.L.R. 1239, 1253 (H.L.) (per Lord Morris). For representative American citations, see supra note 38.

124. The "libel-proof plaintiff" doctrine was first enunciated in 1975 in Cardillo v. Doubleday \& Co., 518 F.2d 638 (2d Cir. 1975). Note, The Libel-Proof Plaintiff Doctrine, 98 HARV. L. REV. 1909 (1985). The doctrine is controversial, see Liberty Lobby, Inc. v. Anderson, 746 F.2d 1563, 1569-70 (D.C. Cir. 1984), rev'd on other grounds, 106 S. Ct. 2505 (1986), and "has not yet generated extensive case law." Note, supra, at 1909.

125. GATLEY ON LIBEL AND SLANDER, supra, note 35, at If 1414 \& n.20.

126. 176 Misc. 685,28 N.Y.S.2d 327 (1941).

127. Id. at 687,28 N.Y.S.2d at 329.

128. It stands, however, in a rather lively tradition of such extreme cases. See, e.g., Heimerle v. Charter, 11 Media L. Rep. (BNA) 1278 (N.Y. Sup. Ct. 1984); Rose v. Borenstein, 119 N.Y.S.2d 288 (1953); Mawe v. Piggott, 4 Ir. R.-C.L. 54 (1869); Hallock v. Miller, 2 Barb. Ch. 630 (1848). 
the "class of persons whose reaction to the publication is the test of the wrongful character of the words used." 129 The common law has formulated various answers to this problem. Sometimes defamation law incorporates the perspective of "a considerable and respectable class in the community"; ${ }^{30}$ sometimes the perspective of "right-thinking persons"; ${ }^{131}$ and sometimes the perspective of "society ... taken as it is."132 No matter what the formulation, however, the essential question is not the protection of individual dignity, but rather which communities the law will assist in the maintenance of their cultural identity.

The concept of reputation as dignity, then, creates two analytically and operationally distinct functions for defamation law: the rehabilitation of individual dignity and the maintenance of communal identity. These two functions can in particular cases pull in opposite directions. Both functions, however, presuppose that individual identity is in soine sense constituted by reputation, and in this regard the concept of reputation as dignity is similar to the concept of reputation as honor. But honor is concerned with attributes of personal identity that sten from the characteristics of particular social roles, whereas dignity is concerned with the aspects of personal identity that stem from membership in the general community. Hence defannation law under a regime of honor protects the status of specific social roles, whereas under a regime of dignity it safeguards the identity of the entire conımunity. Distinction between social roles is accordingly the essence of honor, for it requires defaination law to protect those aspects of a status group that distingnish it froin the rest of society. By contrast the concept of dignity is more difficult to characterize. From the perspective of the individual its essence is inclusion, for under its regime defamation law functions to protect the ability of individuals to be integrated into cominunity inembership. Fron the perspective of society, however, its essence is constitutive, for under the concept of dignity defannation law defines the boundaries and nature of the general community.

At the time of the Enghish Renaissance, the word "dignity" had a ineaning very close to that of honor. Indeed among the earliest usages of "dignity" recorded in the Oxford English Dictionary are those that carry the definition of "honourable or high estate, position, or estimation; hon-

129. Sim v. Stretch, 2 All E.R. 1237, 1240 (1936) (per Lord Atkins)

130. Peck v. Tribune Co., 214 U.S. 185, 190 (1909).

131. Kimmerele v. New York Evening Journal, Inc., 262 N.Y. 99, 186 N.E. 217 (1933); see GATLEY ON L1BEL AND SLANDER, supra note $35, \mathbb{1} 41$.

132. Van Wiginton v. Pulitzer Publishing Co., 218 F. 795, 796 (8th Cir. 1914); see Grant v. Readers Digest, 151 F.2d 733 (2d Cir. 1945), cert. denied, 326 U.S. 797 (1946); Flood v. News \& Courier Co., 71 S.C. 112 , 50 S.E. 637 (1905). 
our, degrees of estimation, rank."133 By our own time, however, "dignity" has come to be viewed as universal and undifferentiated, as part of the "essential . . . worth of every human being." 134 In his massive study of the history of civility, Norbert Elias found that civility, like dignity, was once associated primarily with "a courtly-aristocratic upper class," but that over time the practices of civility were diffused throughout the general society. ${ }^{135}$ Elias explains this diffusion as resulting from society's growing "complexity and functional differentiation" and the consequent "functional dependence of all on all."136 This complex interdependence led to the notion of "civilization" - an outgrowth of civility-as "a concept designating the manners and condition of existing society as a whole."137

This image of "society as a whole" is made possible by the general diffusion of rules of civility. It is an encompassing image of a social entity that transcends particular roles and classes and status groupings. And it is an image that accordingly provides an important social foundation for the contemporary perception of a universal and undifferentiated human dignity. Unless we resort to theories of natural rights or theology, our own perception of "intrinsic" human dignity ${ }^{138}$ can refer to neither more nor less than the potential for every person to be admitted to membership in a society defined by the reciprocal observance of rules of civihity. The concept of reputation as dignity, therefore, presupposes a particular kind of society, a social world that I shall call a "communitarian society."

Communitarian societies and market societies have in common the concept of equality. Just as in market societies all persons are equally subordinated to the market, so in communitarian societies all persons are equally eligible for inclusion within the community. In most other respects, however, market and communitarian societies are radically different. In market societies individuals create their reputation; in communitarian societies individuals are in a very important sense created by their reputation. In market societies reputation is a private good; in communitarian societies it is both a private and a public good. In market societies reputation is a form of property whose value is deternined by

133. 3 OXford ENGLISH Dictionary 356 (James Murray ed. 1933). This meaning resonates in our own usage when, for example, we speak of the "dignity" of the office of the president.

134. Rosenblatt v. Baer, 383 U.S. 75, 92 (1966). For example a modern dictionary defines "dignity" as "intrinsic worth." WEBSTER's ThIRD NEW INTERNATIONAL Dictionary 632 (1976).

135. N. Elias, Power \& Civility 309 (E. Jephcott trans. 1982); see N. Elias, The Civilizing Process (E. Jephcott trans. 1978).

136. N. ELIAS, POWER \& CIVILITY, supra note 135, at 257, 296.

137. N. Elias, The Civilizing Process, supra note 135, at 44 . In a similar vein, Edward Shils has written that the essence of civility is a form of "respect for the common good." Shils, Ideology and Civility, in THE INTELLECTUALS AND THE POWERS AND OTHER ESSAYS 60 (1972). 138. See P. Berger, B. BERGER \& H. KELLNER, supra note 56, at 89. 
the marketplace; in communitarian societies reputation is constitutive of social and individual identity, and its worth cannot be reduced to a monetary value. ${ }^{139}$

It is clear that at present the common law of defamation bears the influence of both the concept of reputation as property and the concept of reputation as dignity. Not surprisingly, such divergent influences have led defamation law im rather different directions. For example the irrebutable presumption of general damages is consistent with the concept of reputation as dignity, but not with the concept of reputation as property. ${ }^{140}$ Conversely, the fact that corporations and other inanimate entities can sue for defamation ${ }^{141}$ is consistent with reputation as property, but not with reputation as dignity.

The conflict within defamation law is so severe that it is incapable even of specifying coherent criteria by which publications can be distinguished as defamatory or nondefamatory. The "classic"142 definition of defamatory words as those injuring "the reputation of another by exposing him to hatred, contempt or ridicule" 143 was clearly oriented toward the concept of reputation as dignity, since it stressed the stigmatizing harms that occur when rules of civility are violated. ${ }^{144}$ But modern commentators view the classic definition as "probably too narrow," because "some suggestions might be very injurious to the reputation of a busi-

139. For this reason a rough indication of the contemporary importance of the concept of reputation as dignity can be seen in the finding of the lowa Libel Research Project that only about $20 \%$ of plaintiffs "appear to have sued to obtain money as compensation for actual material economic harm from the alleged libel." Bezanson, The Libel Suit in Retrospect: What Plaintiffs Want and What Plaintiffs Get, 74 CAL1F. L. Rev. 789, 791 n.7 (1980). Most hibel plaintiffs do not appear to view the availability of money damages as particularly important. Instead the "major motivating factors" behind contemporary libel suits are "restoring reputation, correcting what plaintiffs view as falsity, and vengeance." Id. at 791 see Bezanson, Libel Law and the Realities of Libel Litigation: Setting the Record Straight, 71 IowA L. REv. 226, 227-28 (1985).

140. See supra text accompanying notes $31-45$. In a similar fashion the fact that in most jurisdictions actions for defamation do not survive a plaintiff's death is consistent with the concept of reputation as dignity, but not with the concept of reputation as property. Actions "for injury to property or property rights" characteristically survive a plaintiff's death, whereas defamation actions do not because they are viewed as merely "personal" to the plaintiff. A. HANSON, supra note $35, \S 206$.

141. Restatement (Second) OF TORTS §§ 561-62 (1977); Prosser \& KeETon, supra note 26 , at $779-80$.

142. GatLey on Libel AND SLANDER, supra note 35, at $\{4$ n.20.

143. Parmiter v. Coupland, (1840) 6 M. \& W. ${ }^{*} 105,{ }^{*} 108$, 151 Eng. Rep. 340, 342 (1840) (per Parke B.).

144. The influence of the concept of reputation as dignity is even more evident in subsequent elaborations of this definition. For example, in Kimmerle v. New York Evening Journal, Inc., 262 N.Y. 99, 86 N.E. 217 (1933), the court defined defamatory words as those "which tend to expose one to public hatred, shame, obloquy, contumely, odium, contempt, ridicule, aversion, ostracism, degradation or disgrace, or to induce an evil opinion of one in the minds of right-thinking persons, and to deprive one of their confidence and friendly intercourse in society." Id. at 102, 186 N.E. at 218 (citing Sydney v. MacFadden Newspaper Publishing Corp., 242 N.Y. 208, 151 N.E. 209 (1926)). 
nessman which would not be covered by the definition." ${ }^{145}$ Reservations regarding the definition clearly refiect the influence of the concept of reputation as property, which would imply that words should be defamatory if they impair the market value of an individual's reputation. The strain of straddling these two divergent perspectives is evident in the second Restatement's definition of a defamatory communication:

A communication is defamatory if it tends so to harm the reputation of another as to lower him in the estimation of the community or to deter third persons from associating or dealing with him. ${ }^{146}$

The definition divides into two parts. A cominunication is defamatory if it harms a person's reputation (1) so as "to lower him in the estimation of the community," or (2) so as "to deter third persons from associating or dealing with him." The first part of the definition turns on the meaning of the phrase "the estimation of the community." The phrase refers to the "esteem" with which a "commumity" embraces its members, and so appears to derive from the concept of reputation as dignity. This is confirmed by the Restatement's explanation that "[c]ommunications are often defamatory because they tend to expose another to hatred, ridicule or conteinpt."147

The second part of the definition, however, adopts a nonnormative and purely behavioral account of defamation which turns on the deterrence of "third persons from associating or dealing with" the subject of the communication. This seems designed to capture those cases in which a person's reputation as property is injured even though the person has not fallen in the community's esteein. ${ }^{148}$ The definition evidently uses behavioral criteria as a rough ineasure of loss of niarket value, since the refusal to associate or deal is an overt and measurable sign of the loss of potential goodwill and credit.

But this behavioral approach, if taken literally, leads to absurd

145. Gatley on Libel and Slander, supra note 35, at \4. n.20. An example would be a publication alleging "insolvency not due to discreditable conduct." Id. See L. EldrEDGE, supra note 31, $\$ 7$ at 31 ("Any such definition as [Baron Parke's] is much too narrow and does not encompass many statements which have been held to be defamatory."); Developments in the Law of Defamation, 69 HARV. L. REv. 875, 878 (1956) ("Thus the scope of defamation seems to have been conceived to include more than the lowering of the estimates of character."). Dean Prosser, on the other hand, contended that defamatory words "necessarily" involve "the idea of disgrace." W. Prosser, supra note 2, at 739.

146. RESTATEMENT (SECOND) OF TORTS $\S 559$ (1977). The strain is even more apparent in an early draft of $\S 559$ : "A communication is defamatory if by its meaning it tends to harm the reputation of another or to deter third persons from associating or dealing with him." RESTATEMENT OF TORTS 57 (Tent. Draft No. 12, 1935).

147. RESTATEMENT (SECOND) OF TORTS $\$ 559$ comment b (1977).

148. See supra note 145. Thus the Restatement explains that statements can be defamatory because they "tend to discredit [one's] financial standing in the community, and this is so whether or not [one] is engaged in business or industry." RESTATEMENT (SECOND) OF TORTS $\S 559$ comment b (1977). For variant interpretations of the word "associating," however, see infra note 149. 
results. If I inaccurately say of another that he has a bad cold, people may well be deterred from associating with him, at least until he is well. Yet no court would hold the communication defamatory. ${ }^{149}$ Similarly, to characterize a person incorrectly as a Republican is not defamatory, even though Deinocrats may well be deterred from dealing with him and as a result the person inay lose credit or business opportunities. ${ }^{150}$ In examples like these we instinctively return to the perception that defamation law is primarily meant to sanction communications that breach the ordinary rules of civility. This perception is exemplified by the common law doctrine that "[p]otential for harm, rather than actual harm, is the crux of the wrong." 151 Defamation law understands itself as regulating a specific class of commumications which have the "general tendency" to cause reputational harm; ${ }^{152}$ it does not simply provide compensation for financial or associational losses resulting from untrue commumications generally.

\section{Recapitulation}

In a sense that is not simply metaphorical, a society can be said to inhere in the social apprehension by which its members know and regard each other. From this perspective, the field of reputation is vast and encompassing, virtually coextensive with society itself. It makes little sense in such a context to speak of defamation law as "protecting reputation," for such a task would be at once too enormous and too diffuse. It is therefore necessary, if defamation law is to serve a coherent purpose, to

149. See Veeder, supra note 19, at 50. Yet there is some indication that the drafters of the Restatement meant to embrace precisely this possibility. Thus comment $\mathrm{c}$ to $\$ 559$ states:

Social Aversion. A communication may be defamatory of another although it has no tendency to affect adversely the other's personal or financial reputation. Thus the imputation of certain physical and mental attributes such as disease or insanity are defamatory because they tend to deter third persons from associating with the person so characterized.

To the extent that the drafters meant to define a communication as defamatory simply because it has the tendency to lead to the loss of association, their definition is manifestly overbroad and leads to the unacceptable results described in text. The most plausible interpretation, therefore, is that the loss of association is significant because it is a measure of the loss of reputation as property. A variant interpretation, however, is suggested by the drafters' reference to disease and insanity. An accusation of either insanity or certain "loathesome" diseases, RESTATEMENT (SECOND) OF TORTS $\S 572$ (1977), can be stigmatizing, see E. GoFFMAN, supra note 114, at 54, 87, 89; M. FouCAULT, MADNESS AND CIVILIZATION (R. Howard trans. 1965), and hence such accusations may violate rules of civility. The drafters' concern may thus have been to use defamation law to prohibit breaches of civility rules that do not necessarily reflect on the "personal character" of the victim. RESTATEMENT (SECOND) OF TORTS $\$ 559$ comment c (1977).

150. See Frinzi v. Hanson, 30 Wis. 2d 271, 278, 140 N.W.2d 259, 262 (1966) ("Actual damage does not determine the [defamatory] nature or character of the cause of the injury."); Z. CHAFEE, supra note 7 , at 131 .

151. Herrmann v. Newark Morning Ledger Co., 48 N.J. Super. 420, 441, 138 A.2d 61, 72 (1958).

152. RestatemENT (SECOND) OF TORTS $\$ 559$ comment d (1976). 
define and articulate concepts of reputation that more narrowly define the specific forms of social apprehension to be legally protected.

Given the resolutely antitheoretical stance of the common law, the attempt to isolate such particular concepts of reputation may seem chimerical. The difficulty is compounded by the common law's passion for reducing disputes to money damages, a passion that for defamation law has been "a crippling experience." 153 Nevertheless several of the most umque and important doctrines of common lav defamation are consistent with some concepts of reputation and not with others. ${ }^{154}$ These doctrimal markers can be used to reconstruct the specific concepts of reputation that the common law has been designed to protect.

The three concepts of reputation that have been most influential in the development of common law defamation are those of property, honor, and dignity. These are not the only possible concepts of reputation. ${ }^{155}$ Other cultures, for example, have equated reputation with the judgnent of history and immortal fame. ${ }^{156}$ Our own society recognizes the very special and umique form of reputation acquired by great leaders, heroes, or Nobel Prize wimners. Their reputations are individually earned, and yet, as Professor Bellah reminds us in this Symposium, their reputations are public treasures, not merely private possessions. ${ }^{157}$ The impact of these forms of reputation on the actual shape of common law defamation, however, has been on the whole negligible.

The three concepts of reputation as property, honor, and dignity stand $\mathrm{m}$ ambiguous relationship to each other. There is nothing logically inconsistent about defamation law representing the influences of two or more of these concepts, and indeed some of the "anomalies and absurdities" that have plagued common law defamation can be traced to the

153. J.G. Fleming, AN INTROduction to the LAW of ToRTs 207 (2d ed. 1986); see F. Pollock, supra note 1, at 249; Barrett, Declaratory Judgments for Libel: A Better Alternative, 74 Calif. L. Rev. 847 (1986).

154. Some common law doctrines are of course consistent with many different concepts of reputation. It is important to distinguish the concepts of reputation at work in specific defamation actions from the concepts of reputation that have influenced the development of common law doctrine. It is possible, and perhaps even likely, that particular concepts of reputation have been influential in particular cases without leaving any doctrinally visible residue. For example, this might very well presently be the case with the concept of reputation as honor: juries might be influenced by the concept, even though doctrine is not. See supra text accompanying note 96 . For a discussion of the significant difference between the doctrine and practice of libel law, see $\mathrm{N}$. Rosenberg, Protecting the Best Men: An INTER pretative History of the Law of Libel. 219-22 (1986).

155. For an anthropological survey of various concepts of reputation, see GiFTs AND Poison: THE Polmtics of RepUtATion (F.G. Bailey ed. 1971).

156. See, e.g., H. ARENDT, BETWEen PAST AND Future $44-48$ (1961); D. AdAIR, Fame and the Founding Fathers in FAme And the Founding Fathers: EsSays by Douglas Adair 3 (T. Colbourn ed. 1974).

157. Bellah, supra note 64, at 745. See F. Nietzsche, The Use ANd Aduse of History 12-17 (A. Collins trans. 1949). 
simultaneous and diverse influences of these three competing concepts. ${ }^{158}$ The difficulty arises because each of these concepts presupposes a very different image of social life, and the intellectual consistency of defamation law is strained by the pull of divergent underlying assumptions about the nature of social reality. But tliese divergent and inconsistent assumptions reflect real tensions in the society in which defamation law functions. Our own social world contains important elements of both market and communitarian societies. If tliese tensions resolve themselves, one can expect tlie contours of defamation law to become clearer and its doctrines more internally consistent. An exanıle of this process lias been the gradual disappearance of doctrines peculiarly associated witli the concept of reputation as honor. ${ }^{159}$ But the tensions between a market and communitarian society may in fact be inherent in our culture, in whicli case defaniation law would do well to abandon tlie fiction of protecting a unitary concept of reputation. By acknowledging the differences between reputation as property and reputation as dignity, defaniation law could begin tlie task of devising distinct doctrinal structures appropriate to each form of reputation.

The modern development of defamation law, lowever, lias not been fueled by sucli intrinsic concerns. It lias instead since 1964 been largely responsive to constitutional decisions of the United States Supreme Court. The Court lias used the first amendment as a tool to "resliape the common-law landscape." 160 This process has involved a fascinating and complex interaction between the values of our national Constitution and the various assumptions about social life inherent in the differing conceptions of reputation implicit in comnıon law defamation.

\section{II}

\section{REPUTATION AND THE CONSTITUTION}

For the better part of tlie twentieth century, defamatory communications were viewed as one of those "well-defined and narrowly limited classes of speecli"161 that were beyond the pale of constitutional protection. ${ }^{162}$ This view clianged in 1964 when the United States Supreme Court in New York Times Co. v. Sullivan ${ }^{163}$ lield tliat tlie label of defama-

158. Other anomalies, of course, can only be understood as resulting from the vagaries of defamation law's long and intricate history. See Veeder, The History and Theory of the Law of Defamation, 3 Colum. L. REV. 546 (1903).

159. Pat O'Malley argues that the gradual "disintegration of honour" is due to "[t]he rise of commodity relations, the decline of the fief and the centralization of the state." O'Malley, supra note 48 , at 83 .

160. Philadelphia Newspapers, Inc. v. Hepps, 106 S.Ct. 1558, 1563 (1986).

161. Chaplinsky v. New Hampshire, 315 U.S. 568, 571 (1942).

162. See, e.g., id. at 572; Beauharnais v. Illinois, 343 U.S. 250, $255-57$ (1952).

163. 376 U.S. 254 (1964). 
tion "can claim no talismanic immunity from constitutional limitations. It must be measured by standards that satisfy the First Amendment."164

The specific holding of New York Times was that the first amendment precluded public officials from receiving damages in defamation actions unless they could clearly and convincingly demonstrate that the communication at issue "was made with 'actual malice'-that is, with knowledge that it was false or with reckless disregard of whether it was false or not." 165 The Court justified this holding by reference to specifically first amendment values in fostering "uninhibited, robust, and wideopen"166 public debate and miminizing the possibilities of "self-censorship." 167 The Court viewed these values as so pressing and important that it did not pause to consider the nature of competing interests in the protection of private reputation. It made no difference to the Court's analysis whether the reputation at stake was a form of honor or property or dignity.

From this perspective New York Times was a relatively easy case. But as constitutional regulation of comnion law defamation grew nore extensive, and as the first ainendment values at issue grew more attenuated, it became necessary to address with somewhat inore precision the exact nature of countervailing interests in protecting reputation. ${ }^{168}$ This task proved difficult, however, because the Court was unable to articulate and explicitly evaluate pertinent distinctions annong the various concepts of reputation underlying common law defanation. But since it makes a great deal of difference to the outcome of constitutional analysis whether defamation law safeguards honor, property, or dignity, the implicit and unacknowledged influence of these concepts can nevertheless be perceived in the actual holdings of the Court. Unfortunately the clarity of the Court's reasoning has suffered from its failure directly to analyze the constitutional implications of these concepts, as has its appreciation of some of the more subtle issues raised by the constitutional regulation of common law defamation.

\section{A. Honor and the Constitution}

The concept of honor presupposes a deference society in which individuals are accorded status within a hierarchically arranged social order. For this reason the concept is inconsistent with the egalitarian principles of American democracy. The Constitution itself disapproves of official

164. Id. at 269.

165. Id. at $279-80$.

166. Id. at 270 .

167. Id. at 279.

168. See Dun \& Bradstreet, Inc. v. Greenmoss Builders, Inc., 105 S.Ct. 2939 (1985); Gertz v. Robert Welch, Inc., 418 U.S. 323 (1974); Rosenbloom v. Metromedia, Inc., 403 U.S. 29 (1971). 
honorific status in explicit terms: "No Title of Nobility shall be granted by the United States: And no Person holding any Office of Profit or Trust under then1, shall, without the Consent of the Congress, accept any ... Title, of any kind whatever, fron any King, Prince, or foreign State." 169

The clearest exaniple of the protection of reputation as honor can be found in the law of seditious libel, which uses criminal sanctions to penalize speech that dares to demean the esteem that government and its officials demand by virtue of their status in the community. Seditious hibel protects the "special veneration ... due" to the those who rnle. ${ }^{170}$ As Sir James FitzJames Stephen put it:

Two different views may be taken of the relation between rulers and their subjects. If the ruler is regarded as the superior of the subject, as being by the nature of his position presumably wise and good, the rightful ruler and guide of the whole population, it must necessarily follow that it is wrong to censure him openly, that even if he is mistaken his mistakes should be pointed out with utmost respect, and that whether mistaken or not no censure should be cast upon him likely or designed to diminish his authority.

If on the other hand the ruler is regarded as the agent and servant, and the subject as the wise and good master who is obliged to delegate his power to the so-called ruler because being a multitude he cannot use it himself, it is obvious that this sentiment must be reversed. Every member of the public who censures the ruler for the time being exercises in his own person the right which belongs to the whole of which he forms a part. He is finding fault with his servant.... To those who hold this view fully and carry it out to all its consequences there can be no such offence as sedition. ${ }^{171}$

In New York Times Co. v. Sullivan, the Court held that common law defamation could not be used to shield government officials from criticisn. The reasoning of the opinion turned on a constitutional repudiation of the law of seditious hibel. ${ }^{172}$ Indeed it has been said of New York Times that its special virtue was the restoration of "seditious libel to its essential role ... as the key to the meaning of the First Amendment." "173 This restoration was inade possible, however, by a constitutional inversion of the status relationships protected by seditious hibel. In America, the Court said, government officials are "public servants,"174 and the people are their inasters. Masters have status and rightly demand veneration; servants do not. Hence the Court reaffirmed Madison's view that

169. U.S. ConST. art. I, $\S 9$, cl. 8.

170. F. Holt, supra note 64 , at 90 .

171. J.F. STEPHEN, supra note 59, at 299-300.

172. 376 U.S. at 273-78; Kalven, The New York Times Case: A Note on "The Central Meaning of the First Amendment," 1964 SUP. CT. REv. 191, 204-10.

173. Kalven, supra note 172, at 204.

174. 376 U.S. at 282. 
in "the American form of government," the "censorial power is in the people over the Government, and not in the Government over the people." 175

The rejection of seditious libel in New York Times is predicated upon an implicit rejection of the honorific status of government officials. ${ }^{176}$ In this country such officials are not "the superior of the subject." Since honor is but the internalization of status, the necessary but unarticulated implication of New York Times is that the vindication of official honor is not a constitutionally legitimate function of defamation law. Defamation law cannot be used to protect the "special veneration" claimed by government officials.

This conclusion was reinforced by an alternative holding of New York Times. The plaintiff in New York Times was responsible for the supervision of a city police department; the communication at issue did not identify the plaintiff by name or official position, but instead charged particular instances of potice misconduct. The Court expressed concern $\mathrm{m}$ its opinion that the private relnedies afforded by defamation law might be used to suppress criticism of government, and it therefore ruled that there were constitutional dinensions to the question of whether an attack on government was "of and concerning"177 a particular government official. The Court placed constitutional limits on the ability of defamation law to transmute "impersonal" government criticism "into personal criticism, and hence potential hibel, of the officials of whoin the government is composed." 178

The distinction between official roles and the individuals who occupy them is essential to the concept of rational legal authority. ${ }^{179}$ By giving constitutional sanction to this distinction, New York Times severed the fusion of person and role that is necessary to the concept of honor. In a deference society an affront to the monarchy is also a personal affront to the king, for it reflects on his honor. But the holding of New York Times constitutionally forbids defamation law from protecting this kind of personal identification with public office. ${ }^{180}$

The firm and unmistakable message of New York Times, then, is that the premises by which a deference society is governed are incompatible with the democracy created by the United States Constitution. For this reason the use of defamation law solely to vindicate the honor of public officials will be subject to vigorous and hostile constitutional scru-

175. Id.

176. See N. Rosenberg, supra note 154 , at 263-64.

177. 376 U.S. at 288. See RESTATEMENT (SECOND) OF TORTS $\$ 558(a)$.

178. New York Times, 376 U.S. at 288-92.

179. See supra text accompanying note 93 .

180. See Rosenblatt v. Baer, 383 U.S. 75, 80-83 (1966). 
tiny. ${ }^{181}$ This leaves open the question, however, of the relationship between the Constitution and the use of defamation law to vindicate the honor of persons who do not hold public office.

The question is difficult to analyze because our contemporary attitudes toward honor are so ambiguous. But it seeins clear that since honor flows from the urnque status of a particular role, there is an intrinsic tension between honor and general ideals of egalitarianism. This was quite clear in early nineteenth-century America, when honor was a more tangible social fact. A major indictinent pressed by reformers seeking to abohish the Code of Honor of gentlemen duellists, for example, was that gentlemanly honor was inherently antidemocratic:

The contempt with which duellists treat the opinions and feelings of the community, is a reason why we should cease to confide in them.

The people, whatever men of honor niay think of them, constitute the strength, the virtue, and glory of the nation, and their opinions and wishes demand respect from those who legislate for them. The feelings of the great body of the people are decidedly opposed to duelling. This is manifest from their law on this subject, and from the fact that the mass of the people discard those notions of Gothic honor, resting satisfied with that protection and redress which the law can afford. It is but a handful of men only, conpared with the whole that uphold this bloody system. ... But the opinion of this handful is, by those who conpose it, deemed of far greater consequence, than the opinion and feelings of the great niass of the people. Duellists well know your aversion to their crimes, ... But little do they care for your opmions or your feelings. They move in a sphere too much above you, to let themselves down to the standard of your conceptions, or to give themselves concern about your petty pains. ${ }^{182}$

If duellists were able to use defamation law to vindicate their honor, the law would in effect sanction the social inequality underlying their assertions of honor. In the South, for example, where the protection of white honor was viewed as a matter of grave inportance, ${ }^{183}$ it was as recently as 1957 defamatory to say that a Caucasian was a Negro, because of "the social distinction existing between the races, since libel may be based upon social status." 184 But no black could ever sue for

181. This does not imply that public officials cannot constitutionally prevail in defamation suits. It only means that those doctrinal aspects of defamation law that unambiguousiy protect the honor of public officials, as opposed to their property or dignity, will likely meet with constitutional disapproval.

182. L. BEECHER, The Remedy for Duelling: A Sermon Delivered Before the Presbytery of LongIsland, at the Opening of Their Session at Aquebogue, April 16, 1806, in LYMAN BEECHER AND THE REFORM OF SOCIETY: FOUR SERMONS 24 (1972).

183. B. WyatT-Brown, SOUTHERn HONOR 363 (1982).

184. Bowen v. Independent Pub. Co., 230 S.C. 509, 510, 96 S.E.2d 564, 565 (1957). See, e.g., Jones v. R.L. Polk \& Co., 190 Ala. 243, 67 So. 577 (1915); Natchez Times Pub. Co. v. Dunigan, 221 Miss. 320, 72 So.2d 681 (1954); Flood v. News \& Courier Co., 71 S.C. 112, 50 S.E. 637 (1905). 
defamation upon being called a white, since defamation law understood itself to be enforcing "the intrinsic difference between whites and blacks," a difference inhering in the fact that, "from a social standpoint, the negro race is in inind and inorals inferior to the Caucasian."185 Defamation law, in other words, affirmed the honor of whites by authoritatively denying status to blacks.

The issue is whether the legal affirmation of such status inequality raises constitutional questions. The issue is hard to grasp because it is so difficult to find concrete conteinporary examples of defamation law unambiguously protecting honor, rather than property or dignity. The clearest such exanple is the use of defamation law to protect the status hierarchy of race relations in the South, and it is no accident that we are more likely to analyze the constitutional issues raised in that use of defamation law by reference to specific constitutional concerns located in the thirteenth and fourteenth amendments, than we are to analyze it as an abstract issue of social equahity. Race relations reflect a social cleavage of such deep and important social dimensions as to have becoine an independent inatter of substantive constitutional law. It is likely that whenever defamation law unequivocally protects status inequality, it will be reflecting a social division of similar societal significance, and one that will have been independently conceptualized as a question of substantive constitutional law. The use of law to protect honorific status within the inilitary is one such example. ${ }^{186}$ This suggests that an abstract constitutional analysis of the function of defamation law in protecting private honor is not likely to prove particularly illuminating.

\section{B. The Constitution and Reputation as Property}

If contemporary Americans are uneasy with the concept of honor, they are intimately comfortable with the concept of property. We all live a good part of our hives by the inarketplace and its evaluations. The national faniliarity with property goes back to the country's origins, for the Constitution is as exphicit in its approval of the institution of property as it is definitive in its rejection of official honorific status. The contracts

185. Wolfe v. Georgia Ry. \& Electric Co., 2 Ga. App. 499, 58 S.E. 899, $901-02$ (1907). See Black, The Lawfulness of the Segregation Decisions, 69 YALE L. J. 421, $423-27$ (1960).

186. Military law contains provisions that are essentially equivalent to seditious libel. See, e.g., United States v. Brooks, 44 C.M.R. 873 (1971); United States v. Montgomery, 11 C.M.R. 308 (1953); 10 U.S.C. $\$ 891(3)$, art. 91 (1983); MANUAL FOR CoURTS-MARTIAL OF THE UNITED States art. 88, $89 \S \S 888,889$ (Rev. ed. 1969); G. Davis, A TREatise ON THE Military LAW OF THE UNITED STATES 376-77 (3d ed. 1915). The Supreme Court has traditionally analyzed aspects of military law that may raise constitutional issues as turning on "the different character of the military community and of the military mission." Parker v. Levy, 417 U.S. 733, 758 (1974); see Goldman v. Weinberger, 106 S.Ct. 1310 (1986); Hirschhorn, The Separate Community: Military Uniqueness and Servicemen's Constitutional Rights, 62 N.C.L. REv. 177 (1984). 
clause, ${ }^{187}$ the takings clause, ${ }^{188}$ and the due process clause ${ }^{189}$ are examples of constitutional solicitude for the institution. This solicitude extends even to forms of intangible property that subsist entirely in speech, for the Constitution gives Congress the power to "promote the Progress of Science and the useful Arts, by securing for timited Times to Authors and Inventors the exclusive Right to their respective Writings and Discoveries." 190

From the constitutional point of view, the concept of reputation as property is the least probleinatic of all justifications for defamation law. There have been two occasions when the United States Supreme Court or its members have attempted explicitly to reason from an analysis of the kind of reputation protected by common law defamation to a conclusion about the nature of the constitutional regulation to which such law should be subjected. On each occasion, the Court apprehended the purposes of defamation law within the framework of reputation as property.

The first such occasion was Justice Harlan's dissent in Rosenbloom v. Metromedia, Inc. ${ }^{191}$ His dissent is the clearest and most thoughtful opmion by a Supreme Court Justice addressing the question of the purpose of defaination law, and it forcefully evokes the concept of reputation as property. The opmion rests on the premise that "the States have a perfectly legitimate interest, exercised im a variety of ways, in redressing and preventing careless conduct .... that inflicts actual, measurable injury upon individual citizens." 192 Harlan views the "paramount goal" of defamation law as "compensation for harm," and the kind of harm he has in mind is that which is "susceptible of more or less objective measurement."193 Harlan goes so far as to say that defamation law would be unconstitutional if it were to subject "publishers to jury verdicts for falsehoods that have done the plaintiff" no such harm. ${ }^{194}$

Reputation for Harlan is thus a private good whose value can be objectively measured. The paramount function of defamation law is to provide compensation for the loss of that value. This understanding of reputation is compatible only with the concept of reputation as property. Reputation as dignity is not a value susceptible to objective measurement; and the paramount goal of a defamation law designed to protect dignity would not be coinpensation, but rehabilitation. Harlan's explicit

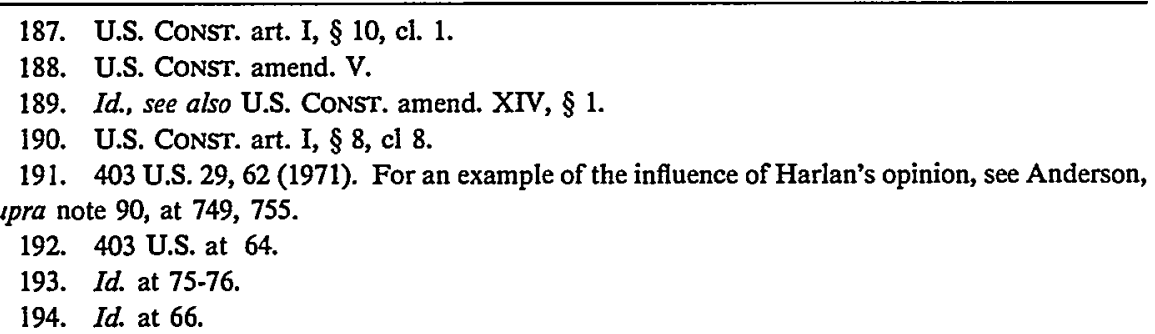


condemnation of the use of defamation law to impose damages in the absence of individual harm means that defamation law cannot be used for the independent purpose of enforcing rules of civility.

The second occasion on which the Court discussed in detail the nature of the reputation interest protected by defamation law was the pivotal decision of Gertz v. Robert Welch, Inc., ${ }^{195}$ in which the Court comprehensively determined the doctrinal framework for first amendment regulation of defamation law. Gertz reaffirmed the constitutional rule that public officials and public figures must demonstrate actual malice before they can prevail in a defamation action. It concluded that private figures must demonstrate fault and that, in the absence of actual malice, pumitive damages nay not be awarded. Gertz reached these conclusions without explicitly assessing the nature of the state's interest in defamation law. But with respect to one important holding Gertz did engage in such an explicit assessment. Gertz held that in the absence of actual malice the common law presumption of damages was unconstitutional, and that plaintiffs would therefore be restricted to "compensation for actual injury."196 Although the manner in which the Court reached this conclusion bears the recognizable infiuence of Harlan's dissent in Rosenbloom, ${ }^{197}$ the Court in Gertz altered Harlan's reasoning in subtle but significant ways.

On its face the reasoning of Gertz is straightforward and uncomplicated. It begins with the premise, reiterated several times, that there is a "strong and legitimate state interest in compensatmg private individuals for injury to reputation." 198 This interest, however, "extends no further than compensation for actual injury." 199 The common law presumption of damages is "an oddity of tort law, for it allows recovery of purportedly coinpensatory dainages without evidence of actual loss."200 Not only does the presumption of damages implicate specifically first amendment concerns which involve encouraging uninhibited speech and discouraging the penalization of unpopular speech, but also, and "[m]ore to the point," states "have no substantial interest in securing for plaintiffs . . . gratuitous awards of money damages far in excess of any actual

195. 418 U.S. 323 (1974).

196. Id. at 349. Gertz never explained why the presumption of damages was constitutional if a defendant published a defamatory untruth with actual malice. See id. at 395 (White, J., dissenting). The point could not have been the particularly heinous behavior of such a defendant since Gertz also specifically held that in cases of actual malice punitive damages could be imposed "to punish reprehensible conduct and to deter its future occurrence." Id. at 350.

197. Robertson, Defamation and the First Amendment: In Praise of Gertz v. Robert Welch, Inc., 54 TEX. L. REV. 199, 208 (1976).

198. Gertz, 418 U.S. at $348-49$.

199. Id. at 349.

200. Id. 
injury."201

This reasoning, like Harlan's before it, is plainly within the framework of reputation as property. It views the primary function of defamation law as compensatory. It correctly perceives that the presumption of damages is anomalous with respect to this function. And it easily concludes that plaintiffs can be restricted "to compensation for actual injury" because the presumption of damages endangers first amendment rights without being supported by any "substantial interest." Like Harlan's dissent im Rosenbloom, the Gertz opinion appears to rule out the use of the presumption of damages to sanction violations of civility rules; if read literally, Gertz concludes that there is no important state imterest involved in the employment of such sanctions.

The matter, however, is not so siniple. Gertz rejects Justice Harlan's requirement that "actual mjury" be objectively measurable, and instead holds that "there need be no evidence which assigns an actual dollar value to the injury."202 Gertz also refuses to define the nature of "actual injury" except to say that it includes, over and above "out-of-pocket loss," such harms as "inipairment of reputation and standing in the community, personal humiliation, and mental anguish and suffering."203 This characterization of actual injury is plainly inconsistent with the concept of reputation as property. While mental anguish and personal humiliation may sometimes accompany the loss of reputation as property, they are not themselves the objects of the law's protection. It is easy to inıagine cases in which imdividuals suffer such emotional harm without an accompanying loss of reputation as property. ${ }^{204}$ If harm to reputation were harm to property, states would have "no substantial interest" in permitting recovery in such cases.

For these reasons the characterization of actual injury in Gertz must be understood as flowing from the influence of a concept of reputation other than that of property. At one level, of course, this influence is obvious, for early on the Gertz opinion cites Justice Stewart's Rosenblatt concurrence. ${ }^{205}$ But it is curious that while Gertz mentions the concept of diginty, it neither develops the concept nor incorporates the concept into its constitutional reasonimg. The influence of the concept of dignity is entirely imphicit, perceptible only in the actual outcome reached by the Court. That outcome is understandable from the perspective of reputation as dignity in the following sense: If a plaintiff has had his dignity

201. Id.

202. Id. at 350 .

203. Id.

204. See, e.g., Time, Inc. v. Firestone, 424 U.S. 448, 460 (1976); Gobin v. Globe Publishing Co., 232 Kan. 1, 649 P.2d 1239 (1982); Salomone v. MacMillan Publishing Co., 77 A.D.2d 501, 429 N.Y.S.2d 441 (1980).

205. 418 U.S. at 341-42; see supra text accompanying note 97. 
impaired by the violation of a civility rule, it is prima facie defensible to compensate him for all injuries which flow from that violation, including mental anguish and personal humiliation. ${ }^{206}$

The difficulty with this interpretation is that Gertz appears to contain no independent requirement that dignity be impaired, and so seems to assume that every defamatory publication will automatically cause harm to individual dignity, although this is not obviously the case. ${ }^{207}$ For example it is possible for a defendant to prove that a defamatory communication was in fact disbeheved by all who heard it. For this reason commentators have charged that Gertz's definition of actual injury converts "the tort of defamation from its common law purpose of protecting reputation into a new remedy for mental distress." 208 It is not clear, however, that the charge is justified. The violation of a civility rule is an accusation that puts a plaintiff's dignity at risk. Even if it could be shown that the accusation is not believed, a plaintiff may still feel stigmatized and excluded, and the feeling would be well captured by notions of anguish and humiliation. In such circuinstances it is a fine question whether liarm to dignity resides in the judgnient of the coinmunity or in the humiliation of the person who believes he has been stigmatized. Certainly it is plausible to maintain that Gertz's resolution of the question is faithful to the concept of reputation as digmity.

What is fascinating about Gertz, however, is that although its reasoning is entirely within the framework of reputation as property, its actual holding is explicable only within the frainework of reputation as digmity. The disjunction between reasoning and outcome is disorienting. It imdicates that although the Court feels most comfortable within the analytical framework of reputation as property, it is confident that the protection of property only incompletely captures the actual purposes of defamation law. The puzzle posed by Gertz is why in the face of this confidence the Court is apparently unwilling frankly and explicitly to mcorporate the protection of reputation as digmity into its constitutional

206. It is important to note that Gertz imposes the actual injury requirement only on those plaintiffs seeking compensatory damages. The requirement thus does not rule out the theoretical possibility that a plaintiff could sue either for rehabiliation of dignity in the absence of damages, or for the retraction of a libelous communication to minimize impairment of property. See Barrett, supra note 153, at 854 Franklin, A Declaratory Judgment Alternative to Current Libel Law, 74 CALIF. L. Rev. 809 (1986); Franklin, Good Names and Bad Law: A Critique of Libel Law and a Proposal, 18 U.S.F. L. Rev. 1 (1983); Hulme, Vindicating Reputation: An Alternative to Damages as a Remedy for Defamation, 30 AM.U.L.REv. 375 (1981); Note, An Alternative to the General-Damage Award for Defamation, 20 STAN. L. REv. 504 (1968); Note, Vindication of the Reputation of a Public Official, 80 HARV. L. REV. 1730 (1967).

207. See supra text accompanying notes 123-25.

208. Anderson, supra note 90, at 757-58. See Ashdown, Gertz and Firestone: A Study in Constitutional Policy-Making, 61 MINN. L. Rev. 645, 670-71 (1977); Eaton, The American Law of Defamation Through Gertz v. Robert Welch, Inc. and Beyond: An Analytical Primer, 61 VA. L. REv. 1349, 1438 (1975). 
calculations as an independent and important purpose of defamation law. This reluctance is a sign of the troubled relationship between the Constitution and the concept of reputation as dignity.

\section{The Constitution and Reputation as Dignity}

We can begin to understand this troubled relationship by reflecting on the facts of New York Times Co. v. Sullivan. ${ }^{209}$ The communication at issue in that case was a full-page advertisement in the New York Times by the "Committee to Defend Martin Luther King and the Struggle for Freedom in the South." The advertisement urged support for the civil rights moveinent in the South, and, without naming individuals, detailed instances of police abuse im the city of Montgomery, Alabama. L. B. Sulhivan, an elected Commissioner of Montgomery responsible for supervision of the police department, sued for libel, seeking $\$ 500,000$ in damages. ${ }^{210}$ On the basis of the advertisement three other Montgomery officials sued for the same amount, and the Governor of Alabama for $\$ 1,000,000 .^{211}$

Sullivan's case was the first to come to trial. The trial judge was Walter Burgwyn Jones, a man deeply hostile to the civil rights movement. He had once published The Confederate Creed, which began:

With unfaltering trust in the God of my fathers, I believe, as a Con-

federate, in obedience to Him; that it is my duty to respect the laws and ancient ways of my people, and to stand up for the right of my State to deterinine what is good for its people in all local affairs. ${ }^{212}$

Local hostility to the Times was so great that it had difficulty finding an Alabama lawyer willing to represent it. When visiting Alabama the regular New York counsel for the Times had to register in a motel under an assumed name. ${ }^{213}$

Although Sullivan "made no effort to prove that he suffered actual pecuniary loss as a result of the alleged libel," he was awarded the full $\$ 500,000$ by the jury. ${ }^{214}$ The rationale for this award was the common law presumption of damages. ${ }^{215}$ It was clear to all concerned, however,

209. 376 U.S. at 254 (1964).

210. Id., at 256-57.

211. Lewis, Annals of Law: The Sullivan Case, THE NEw Yorker, Nov. 5, 1984, at 53. Two weeks after publication of the advertisement, the Times ran a story critical of Southern apartheid entitled Fear and Hatred Grip Birmingham. The article produced another $\$ 3,150,000$ in libel actions against the Times. Id. at 53-54.

212. Id. at 54.

213. Id.

214. 376 U.S. at 256.

215. In affirming the award of damages, the Alabama Supreme Court held that "[t]here is no legal measure of damage in cases of this character." New York Times Co. v. Sullivan, 273 Ala. 656, 686, 144 So.2d 25, 50 (1962) (quoting Haralson, J., in Advertiser Co. v. Jones, 267 Ala. 171, 100 So.2d $696(1959))$. 
that, in the words of Justice Black, "instead of being damaged Commissioner Sullivan's political, social and financial prestige [was] likely . . . enhanced by the Times' publication."216 It was evident from the outset, therefore, that neither Sullivan's individual dignity nor his property had ever seriously been put at risk. ${ }^{217}$

From the standpoint of the common law of defamation, New York Times was not an aberrant case. "Alabama did not create any special rules of law for these defendants. It simply applied the existing principles of the law of hbel."218 The case thus sharply poses the question of exactly what function these common law principles were designed to serve. If neither property nor individual dignity was at stake, to what use was defamation law being applied in the case?

The concept of reputation as dignity creates the potential for two distinct functions for defamation law: the enforcement of rules of civility and the rehabilitation of imdividual dignity. ${ }^{219} \mathrm{New}$ York Times illustrates how defamation law can pursue the first of these functions without implicating the second. In New York Times a local plaintiff and a local jury used the law of defamation to punish those who dared to challenge "the ancient ways" of the Alabama community. ${ }^{220}$ Justice Black, who understood that community quite well, put it this way:

Montgomery is one of the localities in which widespread hostility to desegregation has been manifested. This hostility has sometimes extended itself to persons who favor desegregation, particularly to socalled "outside agitators," a term which can be made to fit papers like the Times, which is published in New York. The scarcity of testimony showing that Commissioner Sullivan suffered any actual damages at all suggests that these feelings of hostility had at least as much to do with rendition of this half-million-dollar verdict as did an appraisal of

\section{Sullivan, 376 U.S. at 294 (Black, J., concurring).}

217. Sullivan's dignity was never at risk because there was never any real possibility that the dominant Montgomery community would regard the statements made about Sullivan as stigmatizing. The jury was predisposed from the outset to accept Sullivan's own interpretation of his behavior. This had little to do with the jury's acceptance or rejection of the "truth" of the Times advertisement, in the sense of its factual accuracy. The concept of "truth" in a civil defamation action can thus be a matter of some complexity, having more to do with the acceptance of "interpretations" than with the determination of "facts." This is particularly true when reputation as dignity is at issue.

218. Kalven, supra note 172, at 196.

219. See supra text accompanying notes 116-33.

220. For a discussion of the nature of that community, see Frankel, The Alabama Lawyer, 19541964: Has the Official Organ Atrophied? 64 CoLuM. L. REv. 1243 (1964). The facts of New York Times suggest that Professor Schauer's equation of jury judgments with majoritarian preferences may not be entirely accurate. See Schauer, The Role of the People in First Amendment Theory, 74 CALIF. L. REV. 761 (1986). Juries speak for local communities, not necessarily for the national society exemplified by the Constitution. In controlling a jury, therefore, a judge is overriding local sentiment. The judge may take this action for a number of different reasons, including the necessity of speaking for the values of a national majority. 
damages. $^{221}$

The doctrinal principle that was the instrument of this hostility was the presumption of damages. The presuinption both punishes those who transgress civility rules of the community and provides the occasion for the reaffirmation of community cohesion and identity. This would be true whether or not Sullivan was a public official, and so the actual holding of New York Times does not directly address the constitutional legitimacy of this function of defamation law. Its constitutional legitimacy is directly challenged in Gertz, however, which imposes an actual injury requirement that repudiates the presumption of damages. Gertz explains this repudiation in terins that make sense only within the framework of the concept of reputation as property. But this explanation is not helpful, since Gertz's holding is inconsistent with this framework and in fact reflects the influence of reputation as dignity.

Perhaps the best explanation for Gertz's holding lies in a case decided three years earlier, Cohen v. California, ${ }^{222}$ issued on the saine day as Rosenbloom v. Metromedia, Inc. ${ }^{223}$ The appellant in Cohen had been convicted of "wearing a jacket bearing the words 'Fuck the Draft." "224 The Court, in an opinion by Justice Harlan, framed the issue as whetler a state could sanction speecl so as to maintain "a suitable level of discourse within the body politic."225 The Court held in the negative, stressing the iniportance of the "constitutional backdrop against which our decision inust be inade":

The constitutional right of free expression is powerful medicime in a society as diverse and populous as ours. It is designed and intended to remove governmental restraints from the arena of public discussion, putting the decision as to what views shall be voiced largely into the hands of each of us, in the hope that the use of such freedom will ultimately produce a more capable citizenry and more perfect polity and in the belief that no other approach would comport with the premise of individual dignity and choice upon which our political system rests. ...

To many, the immediate consequence of this freedom may often appear to be only verbal tumult, discord, and even offensive utterance. These are, however, within established limits, in truth necessary side effects of the broader enduring values which the process of open debate permits us to achieve. That the air may at times seem filled with verbal cacophony is, in this sense not a sign of weakness but of strength. We cannot lose sight of the fact that, in what otherwise might seem a trifling and annoying instance of individual distasteful abuse of a privilege, these

221. Sullivan, 376 U.S. at 294 (Black, J., concurring).

222. 403 U.S. 15 (1971).

223. 403 U.S. 29 (1971).

224. Cohen, 403 U.S. at 16.

225. Id. at 23. 
fundamental societal values are truly implicated. ${ }^{226}$

The passage ranks among the finest statements of first amendment principles in the judicial hiterature, and it rests flatly upon a repudiation of the mamtenance of commumity cohesion and identity as a legitimate justification for the regulation of speech. ${ }^{227}$ Instead of a community constituted and governed by rules of civility, Cohen affirms a polity of "verbal tumult, discord, and even offensive utterance."228 "No other approach," Cohen states, "would comport with the premise of individual dignity and choice upon which our pohtical system rests." This premise is one of our "fundamental societal values."

For Cohen, then, social discord and tumult are associated with respect for a constitutional "premise of individual diguity." From the perspective of defamation law, however, this association makes no sense, for in defamation law human dignity is understood to derive from membership in an orderly and cohesive commumity defined by the reciprocal observance of rules of civility. The constitutional form of "dignity" to which Cohen appeals is thus quite different from the concept of "dignity" that underhies the common law of defamation. For Cohen dignity inheres in a sphere of "imdividual choice" and freedom from government interference, mcluding freedom from the official enforcement of civility rules. "[O]ne man's vulgarity," Cohen observes, "is another's lyric." 229 The assumption behind the observation is that the value of speech must be measured from the perspective of the individual speaker, rather than from the standpoint of community values. The constitutional "premise of individual dignity" upon which Cohen is grounded is thus a forun of individual "autonomy.",230 Commentators have noted the widespread significance of the concept of autonomy to constitutional decisionmaking, ${ }^{231}$

226. Id. at 24-25.

227. As such, Cohen greatly undermines the reasoning of Chaplinsky v. New Hampshire, 315 U.S. 568 (1942), which held that defamatory speech should be exempt from constitutional protection in part because of the "social interest in order and morality." Id. at 572.

228. For this reason Alexander Bickel registered his profound disagreement with the decision:

[T] here is a difference, although in a 1971 decision the Supreme Court managed not to perceive it, between carrying a sign in public that says, Down with the Draft, and a sign that says-I bowdlerize-Fornicate the Draft; between a publication that vigorously criticizes the police and one that depicts them in a cartoon as raping the Statue of Liberty; between using all manner of epithets and employing a fashionable one which is quaintly abbreviated, "mother." This sort of speech constitutes an assault. More, and equally important, it may create a climate, an environment in which conduct and actions that were not possible before become possible.

A. BiCKEL, supra note 112 , at 72 .

229. 403 U.S. at 25.

230. See I. Kant, Groundwork of the Metaphysic of Morals 103 (H.J. Paton trans. 1948) ("Autonomy is . . the ground of the dignity of human nature . ..." (emphasis in original)); S. LUKES, INDIVIDUALISM 52-58 (1973).

231. See, e.g., Eichbaum, Towards an Autonomy-Based Theory of Constitutional Privacy: Beyond the Ideology of Familial Privacy, I4 HARv. C.R. - C.L. 361 (1979); Henkin, Privacy and Autonomy, 74 Colum. L. REv. 1410 (1974); Richards, Sexual Autonomy and the Constitutional 
particularly in the area of the first ainendment; ${ }^{232}$ that it could have influenced so Burkean a Justice as Harlan is itself remarkable evidence of the concept's pervasive importance.

The concept of autonoiny and the concept of reputation as dignity rest on opposing views of individual identity. The concept of reputation as dignity assumes that the identity of an individual is in significant ways the product of the social connections by which he is embedded in and attached to a commumity. ${ }^{233}$ This is why it is important for defamation law to protect and enforce rules of civility, which constitute both individual identity and the commumity which makes that identity possible. The concept of autonomy, on the other hand, assumes that the significant aspects of individual identity are those that are authentically self-created, even if what is created contradicts community values. ${ }^{234}$ The underlying image is captured in Michael Sandel's fine phrase of a self "unencumbered by constitutive attachments."235 This image of the person strongly parallels that presupposed by the notion of reputation as property; in both cases individuals are conceived as having identities that are independent of community attachments. The analogy helps to explain the ease with which the Court incorporates the concept of reputation as property into its constitutional reasoning. ${ }^{236}$

Right to Privacy: A Case Study in Human Rights and the Unwritten Constitution, 30 Hastings L.J. 957, 964 (1979); Smith, The Constitution and Autonomy, 60 TEX. REv. 175 (1982); Wilkinson \& White, Constitutional Protection for Personal Lifestyles, 62 CORNELL L. REV. 563, 611-13 (1977).

The concept of autonomy, of course, is rooted in pervasive and profound cultural developments. As Leszek Kolakowski recently pointed out, "Market economy, rationalist philosophy, liberal political doctrines and institutions, and modern science emerged as interconnected aspects of the same evolution . . ." Kolakowski, The Idolatry of Politics, THE NEw REPUBLIC, June 16, 1986, at 29.

232. T. EMERSON, THE SYSTEM OF FREedoM OF EXPRESSION 6-8 (1970); Baker, The Process of Change and the Liberty Theory of the First Amendment, 55 S. CAL. L. REV. 293 (1981); Baker, Scope of the First Amendment Freedom of Speech, 25 UCLA L. REv. 964 (1978); Redish, The Value of Free Speech, 130 U. PA. L. REV. 591 (1982); Smith, supra note 231, at 185-86; Tribe, Constitutional Calculus: Equal Justice or Economic Efficiency, 98 HARv. L. REv. 592, 618 (1985).

233. See supra text accompanying notes 99-116.

234. I. KANT, supra note 230, at 98-100; H. PEYRE, LITERATURE AND SiNCERITY (1963); L. TRILlING, SINCERITY AND AUTHENTICITY (1971); Schneewind, The Use of Autonomy in Ethical Theory, in RECONSTRUCTING INDIVIDUALISM: AUTONOMY, INDIVIDUALITY, AND THE SELF IN WESTERN THOUGHT 73 (1986).

235. M. SANDEL, Liberalism AND THE Limits OF JUSTICE 178 (1982); see also Sandel, The Procedural Republic and the Unencumbered Self, 12 POLI. THEORY 81 (1984).

236. Conversely, the parallel is suggestive of the causes of the Court's discomfort with the concept of reputation as dignity. This discomfort sometimes reaches extreme proportions. An illustrative example is Justice Brennan's plurality opinion in Rosenbloom v. Metromedia, Inc., 403 U.S. 29 (1971), which is the only effort by a Supreme Court Justice to offer an extended explication of the meaning of "dignity" in Justice Stewart's Rosenblatt concurrence. Justice Brennan interprets Justicc Stewart's discussion of dignity to refer to an individual's "desire to preserve a certain privacy around his personality from unwarranted intrusion ...." 403 U.S. at 48 . While this interpretation is consistent with the concept of autonomy, it is inconsistent with any form of "dignity" that could form a foundation for defamation law. Justice Brennan's gloss on the passage severs the connection 
Autonomy has important implications for the use of defamation law to preserve community cohesion and identity. The message of Cohen, and of course it is a message that conveys a central theme of first amendment jurisprudence, is that individual autonomy demands official respect and therefore tolerance. ${ }^{237}$ Such tolerance, Cohen tells us, is "powerful medicine in a society as diverse and populous as ours."238 Tolerance is the art of livmg with diversity, of finding commonality in the face of difference. The essence of tolerance is the refusal to draw boundaries that shut out the deviant. But while this refusal may be justified by respect for the individuality of the deviant and by the need for different social groups to live together in a land as diverse as the United States, it can nevertheless be deeply antithetical to the constitution of community identity. Only a thoroughly demoralized community can tolerate everything. As Kai Erikson points out,

The deviant is a person whose activities have moved outside the margins of the group, and when the community calls him to account for that vagrancy it is making a statement about the nature and placement of its boundaries. It is declaring how much variability and diversity can be tolerated within the group before it begins to lose its distinctive shape, its unique identity. ${ }^{239}$

A community without boundaries is without shape or identity; if pursued with single-minded determination, tolerance is incompatible with the very possibility of a community. For this reason tolerance as an ideal is incomplete. If community life is to survive, on either the local or national level, tolerance niust at sonie point or another cone to an end. ${ }^{240}$ Exactly where that point is depends a great deal on the impor-

between personal identity and social regard, and hence presupposes a form of "dignity" that cannot be constituted by reputation.

237. See L.C. Bollinger, The Tolerant Society: Freedom of SPEech and Extremist SPEECH IN AMERICA (1986). Tolerance is entirely consistent with the concept of reputation as property. A defamation law that uniformly protects reputation as property is a form of respect for the labor of the person who has created the property. Such a defamation law is tolerant in the sense that it safeguards the goodwill earned by individuals, regardless of whether the content of that goodwill contravenes community norms.

238. 403 U.S. at 24.

239. K. ERIKSON, supra note 116, at 11. See Nicholson, Toleration as a Moral Ideal, in Aspects of Toleration: Philosophical Studies 169 (J. Horton \& S. Mendus eds. 1985).

240. In Cohen Justice Harlan is very much aware of this fact, and is careful to note that constitutional tolerance subsists "within established limits." 403 U.S. at 25 . One of these limits is marked by the doctrine of obscenity, which may be defined as the point at which the constitutional value of tolerance snaps and communities are set free to enforce their "community standards" so as to define the "tone" and "quality" of their community identity. Paris Adult Theatre I v. Slaton, 413 U.S. 49, 58 (1973); Miller v. California, 413 U.S. 15, 33 (1973). It is noteworthy in this regard that obscenity was originally one of the four great branches of criminal libel, the other three being defamation, sedition, and blasphemy. Spencer, Criminal Libel-A Skeleton in the Cupboard (1). 1977 CRIM. L. REv. 383, 383. 
tance one attaches to the intensity of community life and to the exercise of freedom of expression as a reflection of individual autonomy.

This analysis suggests why the Court in Gertz had such difficulty incorporating the protection of reputation as dignity into its constitutional reasoning as a legitimate function of common law defamation. For this function ultimately rests on the value of intolerance, of a community using the force of law to affirm commumity cohesion and identity. This is self-evident in a case like New York Times, where defamation law is used solely to enforce civility rules and to pumsh deviants, and where it serves no other purpose. But it is also true in the more representative case in which defamation law serves the additional function of rehabilitating individual dignity.

Consider, for example, the case of a person who has been called a homosexual and sues for defamation. ${ }^{241}$ He does not seek presumed damages, but desires only to have the court issue an authoritative interpretation that he is not a homosexual. To decide such a case a court must first determine whether the underlying commurication is defamatory; that is, whether it is a sufficiently grave violation of civility rules so as to put the plaintiff's dignity at risk. If the communication is deemed defamatory the court will then decide, in a manner that authoritatively speaks for the commumity, whether the plaintiff was properly stigmatized as a homosexual. The rehabilitation of the plaintiff's reputation thus cannot occur unless the court adopts and affirms the validity of the underlying civility rule whose violation gave rise to the defamation. ${ }^{242}$ Whether the plaimtiff wins or loses, the concept of reputation as dignity will require the court to affirm the community's identity as one that excludes homosexuals. This affirmation is essential to the rehabilitation of the plaintiff's dignity, smce that digmity is conceived as membership in a commumity constituted by civility rules which "intolerantly" distinguish acceptable from unacceptable speech.

For the Supreme Court explicitly to incorporate into its constitutional analysis the principles underlying the concept of reputation as dignity, therefore, would require it to embrace values that directly fly in the face of the essential premise of constitutional autonomy. That premise might conveniently be summarized as "the right to differ as to things that

241. See Matherson v. Marchello, 100 A.D.2d 233, 239, 473 N.Y.S.2d 998, 1005 (1984).

242. In rehabilitating the plaintiff's dignity, the court cannot act as would a neutral and uncommitted observer, as would an anthropologist who finds, records, and applies the civility rules of an exotic culture without herself believing in or affirming their validity. The court can rehabilitate the plaintiff's dignity within the community only if it speaks as a legitimately representative interpreter of the community's civility rules. This has important implications for the range of local communities as to which defamation law can function to rehabilitate dignity, for particularly in a modern pluralistic society a court cannot legitimately represent all communities within its jurisdiction. 
touch the heart of the existing order."243 In Gertz the Court was apparently unwilling to confront this dilemma, and so avoided the tension by rationalizing its holding in the language of reputation as property, even though its holding could not be explained within that framework.

A clear recognition of the tension between reputation as dignity and constitutional autonomy, however, is helpful in understanding the holding in Gertz. In effect the actual injury requirement prohibits the use of defannation law to enforce civility rules, but permits its use to rehabilitate individual dignity. Froin the standpoint of the concept of constitutional autonomy, these functions of defamation law have important differences. Defamation actions to enforce civility rules have only one purpose, which is to maintain community identity, and they achieve this purpose through the punishment of individuals who transgress community norms. They thus pose a stark and uninitigated challenge to constitutional autonomy. Individuals are punished solely to support the supremacy and importance of coinmunity norms. ${ }^{244}$

Defamation actions to rehabilitate individual dignity, on the other hand, also serve to maintain community identity, but do so through the affirmation of civility rules rather than through their enforcement. Such actions also perform the additional function of answering the very real needs of individuals to have those rules authoritatively construed. The tension between constitutional autonomy and actions to rehabilitate individual dignity is thus more diffuse. Community norms are affirmed, rather than enforced. Individuals are not punished for breaking such norms, but rather forced to pay damages for injuries they have caused. The justification for this compromise of individual autonomy is not merely the need to maintam community identity, but also the need to compensate for harms to other individuals. Even in Cohen the Court recoguized that a state could uphold civility norms when "substantial privacy imterests are being invaded in an essentially intolerable manner." 245

These differences suggest that plausible reasons can be offered to support the distinction implied in Gertz between the use of defamation law to enforce rules of civility and its use to rehabilitate individual dignity. ${ }^{246}$ In the end these reasons may or may not be sufficient to justify

243. West Va. State Bd. Educ. v. Barnette, 319 U.S. 624, 642 (1943).

244. In special contexts, like that of the public schools, where egalitarian ideals are relatively dilute and individual claims to autonomy weak, the Court has indicated its willingness to approve punishment solely for the purpose of enforcing "the habits and manners of civility." Bethel School Dist. No. 403 v. Fraser, 106 S.Ct. 3159, 3164 (1986).

245. 403 U.S. at 21.

246. To the extent these reasons are persuasive, however, the distinction must be analyzed in more than simply doctrinal terms. See supra note 154 . For example it must be asked whether the availability of damages for mental anguish and humiliation serves in practice to enforce rules of 
the distinction, but the point is that they can be neither visible nor explicit unless the concept of reputation as dignity is acknowledged and its implications for constitutional autonomy assessed.

The problein with this prescription is that constitutional autonomy and the concept of reputation as dignity rest on opposing views of the nature of human identity. In this country defaination law is ultimately local law and, as such, is enlisted in the aspiration of local conınıunities to create a good and wholesome life for their members. The aspiration, however, is grounded on the assumption that this good life is constitutive of the very identity of the community's meinbers. The concept of autonomy, on the other hand, enianates from a national constitution, and is founded in large measure upon a denial of this assumption. The ultiniate metaphor of our national political life is that of public debate leading to the informed and personal consent of the governed. The metaphor assumes an iniage of mature and independent individuals mutually agreeing to together live a good life, rather than that of individuals socialized by a commurity into a commonly accepted vision of a good life. The differences between these two images are fundamental, and even if they are acknowledged it is not clear how they can ever be resolved.

\section{CONCLUSION}

Gertz has not been the Court's last word on the common law presuniption of damages. The Court addressed the question again in Dun \& Bradstreet, Inc. v. Greenmoss Builders, Inc. ${ }^{247}$ In Dun \& Bradstreet a credit reporting agency had issued an inaccurate report concerning a sniall corporation, Greeumoss Builders, which operated as a constrnction contractor. The credit report falsely stated that Greenmoss Builders had filed a voluntary petition for bankruptcy. The corporation sued for defamation, and the Vermont Suprenie Court held that presumed and punitive danages could be awarded even in the absence of a showing of actual malice. ${ }^{248}$

The United States Suprenie Court affirmed the judgment in a decision divided among four separate opinions, no one of which spoke for the Court. Chief Justice Burger and Justice White each wrote a separate opinion to the effect that Gertz should be overruled and that the holding

civility rather than simply to provide compensation for actual injuries caused by the loss of individual dignity.

247. 105 S.Ct. 2939 (1985).

248. The Vermont Supreme Court interpreted Gertz as imposing the actual injury requirement only in cases where the defendant was a member of the media. Greenmoss Builders, Inc. v. Dun \& Bradstreet, Inc., 143 Vt. 66, 72-76, 461 A.2d 414, 417-19 (1983), aff'd on other grounds, 105 S.Ct. 2939 (1985). 
of New York Times should be reconsidered. Justice Brennan dissented, and was joined by Justices Marshall, Blackmun, and Stevens. The judgment of the Court was announced by Justice Powell who, in an opinion jomed by Justices Rehnquist and O'Connor, held that the common law presumption of damages is constitutional if the plaintiff is a private figure and if the communication at issue does not involve "Inatters of public concern."249

Most of the debate within the Court turned on questions of first amendment policy. Only Justice Powell attempted to craft a decision keyed to the nature of the state's interests in protecting reputation. Powell undertook to "einploy the approach approved in Gertz and balance the State's interest in coinpensating private individuals for injury to their reputation against the First Amendment interest in protecting this type of expression."250 Justice Powell cited Stewart's Rosenblatt concurrence as authority for the view that the state's interest in protecting reputation is that of safeguarding "our basic concept of the essential dignity and worth of every huinan being."2s1 And Justice Powell deferred to the state's mterest in maintaining a presumption of dainages because of "the experience and judgment of history that "proof of actual damage will be impossible in a great inany cases." "252

The root difficulty with Justice Powell's opinion is that it frames the issue to be resolved as an abstract conflict between the first amendinent and something called "reputation." Although the issue is usually framed in exactly this way, ${ }^{253}$ the formulation is, as Dun \& Bradstreet itself illustrates, deeply misleading. Reputation is not a single idea, but is instead a mẽlange of several different concepts. Each concept demands its own constitutional analysis. The failure to understand this seriously undercuts the force of Justice Powell's opinion. For example, although Justice Powell justifies defaination law in terms of the protection of human dignity, the plaintiff in Dun \& Bradstreet was a corporation that could advance no conceivable clain to such dignity. ${ }^{254}$ It was clear from the

249. 105 S.Ct. at 2946. Justice Powell also held that punitive damages could be awarded in such circumstances even in the absence of a showing of actual malice. The "public concern" standard has recently been incorporated into a majority Court opinion. See Philadelphia Newspapers, Inc. v. Hepps, 106 S.Ct. 1558 (1986).

250. 105 S.Ct. at $2944-45$.

251. Id. at 2945 (quoting Rosenblatt v. Baer, 383 U.S. 75, 92 (1966) (Stewart, J., concurring)).

252. 105 S.Ct. at 2946 (quoting W. Prosser, supra note $2, \S 112$, at 765). Such appeals to history and experience have traditionally been the source of many of the "anomalies and absurdities" that have plagued common law defamation. See, e.g., RESTATEMENT (SECOND) OF TORTS $\S 568$ comment b at 180 (1977); T. STARKIE, supra note 14, at 130; Veeder, supra notc 158, at 546.

253. See, e.g., Brosnahan, From Times v. Sullivan to Gertz v. Welch: Ten Years of Balancing Libel Law and the First Amendment, 26 Hastings L. J. 777, 777 (1975); Robertson, supra note 197, at 204.

254. See Martin Marietta Corp. v. Evening Star Newspaper Co., 417 F. Supp. 947, 954-55 
outset that the harm suffered by the plaintiff, if any, was only to its corporate goodwill. In such a context the presumption of damages is anomalous at best. This is amply illustrated by the facts of Dun \& Bradstreet: the defamatory "credit report was made available to only five subscribers, who, under the terms of the subscription agreement, could not disseminate it further."2ss In effect, therefore, the reasons underlying Justice Powell's opimion had virtually no application to the facts of the case actually before him. These reasons must instead be interpreted as addressing a different and more general issue. Once the distinction between reputation as property and reputation as dignity is grasped, this issue can be seen as identical to the one which underlay Gertz. It is the complex and profoundly significant issue of striking a balance between the protection of constitutional autonomy and the maintenance of commumity cohesion and identity.

Dun \& Bradstreet perfectly illustrates the importance of separating reputation into its constituent concepts. Because he viewed reputation as a single, undifferentiated interest, Justice Powell was led to address an issue that was not present in the case before him, and to reach a judgment that was highly questionable in light of the specific facts of that case. Distinguishing among reputation as honor, property, and dignity will not magically dispel the serious dileminas that reside in the constitutional regulation of common law defamation. Significant and intractable constitutional tensions will remain. But at least these tensions will be defined and their subtleties addressed, and they will no longer indiscriminately inflame all aspects of the relationship between the Constitution and defamation law.

Quite apart from its imphications for constitutional law, the recognition of the distinct concepts of reputation underlying defamation law should be of some relevance to the development of common law doctrine. Instead of constructing rules and definitions that awkwardly attempt to span the gulf separating reputation as property from reputation as dignity, the two aspects of reputation can be distinguished and managed through different doctrinal structures. We need to reassess, for example, the relationship between the protection of reputation as property and the tort of injurious falsehood. In a similar way we must reevaluate the connections between the protection of reputation as dignity and the various torts protecting privacy and emotional well-being. The role of damages in protecting reputation as dignity requires reappraisal, as do the limitations and desirability of using courts to maintain community identity and cohesion through the enforcement of rules of civility.

(D.D.C. 1976); M. Dan-Cohen, Rights, Persons, And Organizations: A Legal Theory For BUREAUCRATIC SOCIETY (1986).

255. 105 S.Ct. at 2947 (opinion of Powell, J.). 
But these are all projects for another day. For the moment it is enough to begin to appreciate the intricate and varied social foundations of the common law of defamation. 